\title{
Jurisdição, Incerteza e Estado de Direito'
}

\author{
Joaquim Falcão ${ }^{2}$ \\ Luís Fernando Schuartz ${ }^{3}$ \\ Diego Werneck Arguelhes ${ }^{4}$
}

\section{Introdução}

O objetivo principal deste artigo é contribuir para a discussão sobre a relação entre direito e performance dos mercados de crédito - e, por essa via, sobre a relação entre direito e desenvolvimento econômico. No Brasil, o tema foi novamente colocado em pauta a partir da publicação de um artigo de Pérsio Arida, Edmar Bacha e André Lara-Resende, intitulado "Credit, Interest and Jurisdictional Uncertainty: Conjectures on the Case of Brazil", 5 o qual introduz a "incerteza jurisdicional" como principal determinante da elevada taxa de juros de curto prazo vigente no país e da inexistência de mercado de crédito de longo prazo. O texto de Arida, Bacha e LaraResende (“ABL") é parte de uma extensa literatura econômica que associa o desenvolvimento financeiro de um dado país ao grau de proteção nele oferecido à expectativa que os credores têm de que seus direitos e os direitos de propriedade em geral serāo respeitados. ${ }^{6}$ A contribuição que se pretende dar com este artigo é o aporte de uma perspectiva jurídica a essa discussão mais ampla, motivada pela convicção de que as explicações de natureza econômica, bem como as recomendaçōes - mais ou menos

1 Os autores gostariam de agradecer ao economista Pedro Cézar de Andrade pelos valiosos comentários nas discussōes de preparação deste paper.

2 Diretor e Professor da Escola de Direito do Rio de Janeiro da Fundação Getulio Vargas.

3 Professor Titular da Escola de Direito do Rio de Janeiro da Fundaçāo Getulio Vargas.

4 Professor Assistente da Escola de Direito do Rio de Janeiro da Fundação Getulio Vargas.

5 Giavazzi, Goldfajn e Herrera (Orgs.), Inflation targeting, debt, and the Brazilian experience: 1999 to 2003. Cambridge, MA: MIT Press, 2005.

- Ver, entre outros, La Porta, Lopez-de-Silanes, Shleifer e Vishny, "Law and finance", Journal of Political Economy, 106, 6, 1998. Para uma visão panorâmica, ver Beck e Levine, "Legal institutions and financial development", World Bank Policy Research Working Paper 3136, 2003. 
explícitas - de política pública nestas baseadas, devem incluir uma compreensão do fenômeno jurídico em sua real complexidade.

O foco do artigo é a funçāo jurisdicional, i.e., a função mediante a qual o Estado, sobretudo por meio dos juízes, aplica o direito vigente na solução jurídica dos mais variados conflitos e controvérsias. Mais especificamente, a análise tratará das incertezas introduzidas pela função jurisdicional no ambiente econômico, e, reversamente, das incertezas introduzidas pelo ambiente econômico na função jurisdicional. No Brasil, o exercício da função jurisdicional tem sido objeto de críticas, sobretudo de economistas e empresários, em nome dos efeitos perversos que o mau funcionamento do Judiciário teria sobre os mais diversos mercados. No geral, essas críticas se organizam em torno de dois conjuntos de problemas: o da morosidade e o da politização (vale dizer, a excessiva - por ser supostamente contrária ao que diria o "texto legal" - sensibilidade dos juízes aos interesses e às consequiências "sociais" associadas às suas decisōes) do Poder Judiciário brasileiro.

Segundo a versão mais corrente da crítica à performance judicial baseada nessa idéia de "politização", o Judiciário estaria, em última instância, utilizando o seu poder decisório para uma finalidade política, em detrimento da prometida, devida e esperada obediência ao direito. Esse "neopaternalismo judicial", porém - continua o argumento, sobretudo da parte de autores com alguma formaçāo em law and economics -, apesar de pretender se legitimar justamente nas suas conseqüências sociais positivas, teria efeitos perversos ao aumentar a incerteza no sistema econômico, prejudicar justamente os agentes que pretenderia estar protegendo e, com isso, afetar negativamente o desenvolvimento do país a longo prazo.

Boa parte deste clamor para que os juízes sejam mais "esclarecidos" - em outras palavras, para que pensem corretamente nas conseqüências econômicas de suas decisōes que desconfirmem as expectativas de determinadas categorias de agentes econômicos - é, pode-se dizer sem injustiça, fruto de desconhecimento quanto à realidade institucional e às restrições de natureza cognitiva que, estruturalmente, afetam o ofício do juiz. ${ }^{i} \mathrm{O}$ ideal de atuação jurisdicional pressuposto por um subconjunto considerável dos críticos ignora as complexidades que os agentes envolvidos em um processo de argumentação jurídica enfrentam para aplicar normas gerais a casos particulares. A idéia é a de que nem toda decisão judicial que contraria as expectativas dos agentes privados pode ser validamente apontada como algo negativo, em particular, como fator de insegurança jurídica. Dadas certas características estruturais do tipo de raciocínio envolvido na aplicaçāo do direito, em muitas situaçōes o juiz se vè diante de um conjunto não unitário de decisões para o caso concreto que são compativeis com o direito vigente. Mesmo que a escolha por uma dessas respostas frustre expectativas subjetivas das partes - e ela quase sempre frustrará a da parte perdedora -, estaremos diante de uma incerteza de um tipo que chamaremos de estrutural, no sentido de ser inerente ao normal funcionamento de um sistema jurídico moderno. Apenas a insegurança jurídica gerada por um tipo de incerteza que qualificaremos, em contraposição à estrutural, de patológica é que pode e deve ser combatida.

A respeito, ver seçāo 3.2 infra. 
Evidentemente, é possível e necessário formular críticas à performance do Poder Judiciário brasileiro - seja quanto ao procedimento decisório (morosidade), seja quanto ao conteúdo das decisões ("politização"). Essas críticas são bem-vindas sob a condição de que não partam de percepções equivocadas sobre a realidade institucional na qual as decisões judiciais são tomadas. Existem obviamente críticas ilustradas e pertinentes a um esforço coletivo de reflexão para o aperfeiçoamento das instituições jurídicas brasileiras, que certamente podem e devem se aprimorar ern diversos aspectos. Foi partindo dessa premissa que se fizeram as opçōes temáticas e se traçou a estratégia expositiva do artigo. Este não deve ser lido, portanto, como um manifesto em defesa do Poder Judiciário brasileiro, mas sim como uma tentativa de trazer novos ingredientes a um debate inteiramente válido, porém pouco preocupado até o momento em olhar a realidade de uma perspectiva interna ao sistema jurídico.

\section{Estado, jurisdição e incerteza}

\section{I Um Exemplo: "Incerteza jurisdicional" e taxa de juros}

Uma maneira de encaminhar a discussão acerca da contribuição específica dos juízes brasileiros para o incremento dos riscos do investidor é tomar como ponto de partida a explicação sugerida em $A B L$ para a inexistência de um mercado de crédito de longo prazo e os elevados níveis da taxa de juros de curto prazo no Brasil. Segundo os autores, a principal causa para ambos os fenômenos estaria na incerteza associada ao cumprimento de contratos no âmbito da jurisdição brasileira, por eles batizada de "incerteza jurisdicional" (jurisdictional uncertainty).

Essa explicação para o elevado nível da taxa de juros foi recentemente posta em questão em um paper de autoria de Fernando Gonçalves, Marcio Holland e Andrei Spacov. ${ }^{8}$ Os autores se propōem a testar econometricamente a conjectura apresentada em ABL, utilizando dados de painel. Para isso, em um primeiro estágio, traduzem a referida conjectura em um modelo quantitativo, determinando os sinais algébricos para os parâmetros do modelo que seriam consistentes com a conjectura (e algumas variações). No segundo estágio, uma amostra de 50 países é usada para a realização do teste econométrico. Os resultados do teste não suportam a conjectura apresentada por $\mathrm{ABL}$ (nem tampouco as suas variações) de que a incerteza associada à jurisdição brasileira seria o principal fator a determinar a elevada taxa de juros vigente no país. Os dados, ao invés disso, sugerem que as tradicionais explicaçōes fiscais e monetárias seriam mais plausíveis que a explicação alternativa proposta por ABL.

Não é nem poderia ser nossa pretensão arbitrar o debate econômico acerca da validade da hipótese introduzida por $\mathrm{ABL} .{ }^{9} \mathrm{~A}$ controvérsia interessa mais como

\footnotetext{
8 Gonçalves, Holland e Spacov, “Can jurisdictional uncertainty and capital controls explain the high level of real interest rates in Brazil?", 2005.

9 Para uma posiçāo mais cautelosa em relaçāo ao tema, ver A. C. Pinheiro: "[...] é preciso não sobre-estimar a importância dos fatores legais e judiciais na explicação dos altos spreads bancários e do baixo volume de crédito no Brasil. A instabilidade macroeconômica, a elevada divida pública, os impostos, etc. também têm uma influência determinante na estrutura do mercado de crédito brasilei-
} 
exemplo referente a uma classe de problemas cujos enfrentamento e solução requerem uma maior sensibilidade e um conhecimento especificamente jurídicos. Antes de chegarmos lá, no entanto, será oportuno explorar um pouco mais o argumento de $\mathrm{ABL}$ enquanto guia para localizarmos precisamente a parte que toca ao Poder Judiciário na criação de incerteza jurisdicional - supondo que o conceito é empiricamente relevante.

Ao contrário das aparências, a expressāo incerteza jurisdicional nāo se refere exclusiva, ou mesmo predominantemente, a incertezas produzidas por decisões judiciais. A extensão do conceito, segundo os autores, é mais ampla, pois inclui os riscos associados a qualquer "ato do Príncipe" que modifique o valor de contratos antes ou após o momento de sua execução - e não apenas o risco associado a uma interpretação judicial desfavorável -, riscos esses manifestados em um suposto "viés anticredor", cuja existência os autores acreditam poder conectar a fatores históricos e culturais.

De fato, o conceito de incerteza jurisdicional é assim caracterizado por ABL: "It is an uncertainty of a diffuse character that permeates the decisions of the executive, legislative and judiciary and manifests itself predominantly as an antisaver and anti-creditor bias [...]. In the Brazilian case, jurisdictional uncertainty may thus be decomposed, in its anti-creditor bias, as the risk of acts of the Prince changing the value of contracts before or at the moment of their execution and as the risk of an unfavorable court ruling." Nesses termos, a incerteza jurisdicional seria algo cuja produção é de responsabilidade dos três Poderes da República, i.e., do Poder Público em toda sua extensão. Não só as decisões judiciais, mas também os atos normativos do Poder Legislativo (e. g., as leis) e os atos do Poder Executivo (e. g., decretos, regulamentos e atos administrativos em geral) seriam fontes de incerteza jurisdicional. Desse lado, a única limitação da extensão do conceito vem do atributo do "viés anticredor", enquanto algo próprio aos atos qualificáveis como produtores de incerteza jurisdicional.

Nesse sentido, o artigo não trata apenas do que poderíamos denominar de incerteza judicial. Embora no texto sejam utilizados exemplos que enfatizam o suposto "viés anticredor" dos juizes, o artigo não ignora, por exemplo, a possibilidade de o tal viés anticredor se expressar não na tomada da decisão judicial, mas em atos normativos anteriores à decisāo, originários do Poder Legislativo ou do Poder Executivo, pelos quais o magistrado deveria (na visão tradicional a respeito da divisāo de poderes em um Estado Democrático de Direito) se pautar. Ou seja, situações nas quais o Judiciário não seria a fonte primária da incerteza jurisdicional.

ro" ("O componente judicial dos spreads bancários". In: Banco Central do Brasil. Economia bancária e crédito: avaliaçāo de 4 anos do projeto juros e spread bancário. Brasília, 2003. p. 34-43. Disponível em: <http://www.bcb.gov.br/?RED - SPREAD>. Acesso em: 10.01.2004). Em outro trabalho, Castelar observa ainda que " $[\ldots]$ para reduzir os spreads o governo vem tentando combater a inadimplência, facilitando o acesso a informações sobre maus pagadores e buscando mudanças que reduzam o risco de crédito. Pouco tem sido feito, porém. para aumentar a competição no setor bancário, o que permitiria reduzir a margem líquida e os custos administrativos, que são altos no Brasil, para padrōes internacionais. De fato, tanto o Banco Central quanto o FMI têm estudos que mostram que os grandes bancos brasileiros têm significativo poder de mercado, e que a estrutura nāo competitiva do setor ajuda a explicar os elevados spreads bancários" "“Concor rência e spreads bancários", publicado no jornal Valor Econômico de 25 de julho de 2003). 
Poderíamos citar, ilustrativamente, a Lei $n^{\circ} 8.009 / 90$ - que torna impenhorável o "imóvel residencial próprio do casal ou da entidade familiar" - como exemplo de "ato do príncipe com viés anticredor", um ato do Legislativo que os juízes são obrigados a aplicar em todo processo de execução. Analogamente, o artigo 730 do Código de Processo Civil estabelece que, uma vez citada para pagar quantia certa, a Fazenda Pública tem dez dias para opor embargos à execução, enquanto os devedores privados têm um prazo de apenas 24 horas para tomar a mesma providência.

Evidentemente, novos atos do Legislativo ou do Executivo podem atenuar, intensificar ou até inverter o conteúdo desse tipo de viés. Até recentemente, no processo de execução cabia ao devedor indicar os bens a serem penhorados para satisfação da dívida. Assim, era comum o devedor indicar bens inexistentes, ou que já tinham sido penhorados em outros processos de execução, com o simples intuito de atrasar a satisfação do crédito. Contudo, com a promulgação da Lei $n^{\circ}$ $11.232 / 05$, que acresce ao Código de Processo Civil o artigo $475-\mathrm{I}, \$ 3^{\circ}$, passou a ser do exeqüente a faculdade de indicar os bens a serem penhorados - uma mudança legislativa que vem sendo considerada por advogados empresariais como favorável ao credor na execução. ${ }^{10}$ Antes da alteração legislativa, as decisões judiciais que permitissem ao devedor indicar os bens que seriam penhorados poderiam gerar problemas para o credor. Após a referida alteração, os juízes devem passar a garantir ao credor essa prerrogativa. Em ambas as situaçōes, o Judiciário terá cumprido seu papel normal, sem que a ele se possa atribuir responsabilidade primária pelo conteúdo da decisão que favoreceu esta ou aquela parte.

Adicionalmente, para bem caracterizar as fontes públicas de incerteza jurisdicional seria ainda necessário especificar que a responsabilidade do Poder Executivo não se limita a seus atos normativos, mas se estende também aos atos decorrentes de dois outros aspectos de sua atuação: como agente econômico (isto é, como parte contratante propriamente dita) e como litigante, capaz de contribuir para a morosidade judicial ao submeter à apreciação judicial lides temerárias e abusar de estratégias recursais procrastinatórias. Como veremos adiante, a morosidade - que a atuação do Executivo no Brasil tende a alimentar - é uma das fontes de incerteza judicial.

Entretanto, mesmo com estas qualificaçōes adicionais, a extensão do conceito de incerteza jurisdicional é excessivamente excludente. Nos termos de ABL, nenhum ato que não seja emanado pelo Poder Público é fonte de incerteza jurisdicional. Ficam de fora todos os atos dos agentes econômicos privados, incluindo os atos envolvidos na negociação e na elaboração de contratos cujo valor é afetado por "atos do Príncipe” ou por uma decisāo judicial desfavorável. Em outras palavras, para ABL o credor - ou, em geral, o agente econômico privado - nunca é co-responsável pelos riscos a que se refere o conceito de incerteza jurisdicional.

Esse dado é importante, especialmente quando pretendemos nos aproximar, analiticamente, de uma caracterizaçāo da responsabilidade do Poder Judiciário enquanto fonte primária de incerteza jurisdicional entendida em uma acepção crítica. De fato, a exclusão do que não é público da extensão do conceito de incerteza jurisdicional pres-

10 Cf. a reportagem "Alteração em código já movimenta escritórios", publicada no jornal Valor Econômico de 28 de dezembro de 2005. 
supōe, nos casos de decisāo judicial contrária ao interesse do credor, que tal decisão confronta um negócio jurídico cuja licitude está acima de toda suspeita. É só quando pressupomos que o contrato é perfeito - no sentido da ausência de dúvidas juridicamente razoáveis quanto ao conteúdo semântico dos seus termos e à sua legalidade -, que nos tornamos realmente autorizados a isentar as partes contratantes de toda e qualquer responsabilidade pelos riscos de interpretaçōes ou decisōes judiciais contrárias aos interesses de uma delas. Se a premissa da perfeição do contrato não se verifica, são as partes do contrato elas mesmas a responder primária, ou no mínimo concorrentemente, pelos mencionados riscos. Nessa hipótese, aparentemente não haveria mais que se falar em presença de incerteza jurisdicional (ao menos, não da incerteza do tipo judicial). Este ponto será retomado e aprofundado na seção 4 infra.

Para ABL, portanto, incerteza jurisdicional é produto exclusivo do Poder Público, podendo decompor-se, de um ponto de vista genético, em (i) legislativa, (ii) executiva e (iii) judicial. Isolar a incerteza jurisdicional do tipo judicial requer, em conseqüência, a diferenciação entre aquilo que é contribuição autônoma do Judiciário para o incremento dos riscos do credor, de um lado, e os eventos "desfavoráveis" ao credor que se verificam no âmbito do Judiciário, em decorrência de fatores de incremento dos referidos riscos atribuíveis primariamente ao Poder Legislativo, ao Poder Executivo e às próprias partes contratantes, de outro.

As duas subseções que seguem aludem aos dois grandes complexos de problemas imputados ao Judiciário sob a rubrica da "ineficiência judicial"," quais sejam, o problema da morosidade do Poder Judiciário (2.2.), e o problema da parcialidade e falta de previsibilidade das decisões judiciais (2.3).

\subsection{Incerteza quanto aos meios: o exemplo da morosidade do Poder Judiciário}

Há dois aspectos diferentes em relação aos quais se pode falar mais especificamente de "incerteza judicial": quanto aos meios da decisão e quanto ao seu conteúdo. A primeira diz respeito à aplicação das normas que devem reger o processo de tomada de decisão judicial - por exemplo, ao respeito dos prazos previstos no Código de Processo Civil para que o juiz dê a sentença. Já a incerteza quanto ao conteúdo da decisão propriamente dito se refere às expectativas (normativas ou cognitivas) que ela frustra ou confirma quando é tomada. O suposto viés anticredor, expresso em decisões que contrariam diretamente e de forma não fundamentada uma norma jurídica válida, seria um exemplo de incerteza nesse segundo sentido.

Não existe relação necessária entre os dois tipos de incerteza. ${ }^{12}$ Uma decisão pode ser simultaneamente certa quanto aos meios e incerta quanto aos resultados, desde

11 Ver M. Aith, "O impacto do Judiciário nas atividades das instituiçōes financeiras", in: A. C. Pinheiro (Org.). O Judiciário e a economia no Brasil, 2000; e A. C. Pinheiro, "O componente judicial dos spreads bancários", 2003.

12 A distinçāo aqui traçada é análoga à distinçāo entre "incerteza/certeza nos meios" e "incerteza/certeza nos resultados" desenvolvida e aplicada por Adam Przeworski para a análise de regimes políticos, especialmente em democracias jovens, recém-saidas de governos autoritários ou ditatoriais. Segundo 
que: (1) seja tomada ao final de um processo cujas etapas e condiçōes são previamente fixadas e conhecidas pelos destinatários da decisāo, e (2) o seu conteúdo não possa ser previamente determinado como favorável a uma parte e desfavorável à outra, exceto quando a previsão se fundar em uma antecipação coerente da interpretação que o juiz fará das normas jurídicas válidas e aplicáveis e dos fatos do caso. Entendemos que ambos os elementos, embora afetem de forma diferente a produção de decisões judiciais, podem contribuir para a incerteza jurisdicional.

No âmbito da incerteza quanto aos meios, a demora na obtenção de uma decisão judicial definitiva é usualmente percebida como o problema mais grave da administração da justiça no Brasil. ${ }^{13,14}$ Essa demora afeta negativamente os mercados de crédito de três formas diferentes: (i) ela tende a tornar mais atrativa

Przeworski, uma das principais características do regime democrático é a combinação de previsibilidade nos meios da tomada de decisōes políticas com imprevisibilidade no seu conteúdo. A democracia exige "regras do jogo" claras e previamente estabelecidas e é incompativel com a determinação a priori dos vencedores do processo político (A. Przeworski, "Ama a incerteza e serás democrático". Novos Estudos CEBRAP, $n^{9} 9$, jul. 1984).

13 Em relação à presente subseção e às duas seguintes, ver $\mathrm{A}$. C. Pinheiro, "O componente judicial dos spreads bancários" (2003). O alto custo de se recorrer ao Judiciário para resolver conflitos também tem sido apontado por diversos estudos como prejudicial ao desenvolvimento da economia do país. Cf., nesse sentido, o relatório "Doing business in 2004", elaborado pelo Banco Mundial. Um dos indicadores utilizados no estudo para medir a eficiência do Judiciário dos países analisados foi o custo do enforcement de um contrato pela via judicial. No Brasil, este custo chegaria a 2,4\% da renda per capita. $O$ menor custo global foi encontrado na Jordânia $(0,3 \%)$, seguido de perto pelos EUA $(0,4 \%)$, sendo que o custo médio dos países da América Latina e do Caribe foi de $39 \%$. Os dados do relatório referentes ao Brasil ("Perfil do Brasil") estāo disponíveis no site < http:/www.obancomundial.org >. Por outro lado, é importante não deixar de mencionar a ineficiência gerencial como causa nāo desprezivel de lentidāo da Justiça - e possivelmente mais significativa do que os custos do processo. Ainda que nāo esteja diretamente associada à funçāo judicante do juiz, tal ineficiência é algo que, quando constatada, lhe pode ser, em princípio, justamente imputada. No Brasil, ao contrário do que ocorre em muitos outros paises, os próprios juízes têm a responsabilidade pela administraçāo dos tribunais. Dessa forma, seria coerente esperar dos magistrados um mínimo de capacitação profissional para a gestāo das serventias judiciais. Contudo, os juízes brasileiros - como de resto todos os bacharéis - nāo têm em sua formação nada que os prepare para o desafio de administrar suas varas, câmaras e juizados com recursos escassos, carga excessiva de trabalho e rotinas de trabalho arcaicas. Como observa, por exemplo, J. R. de Lima Lopes, "[e]mbora os códigos processuais sejam grandes rotinas elevadas à categoria de lei visando garantir direitos fundamentais, nāo se vê gente especializada na administração forense, não há serviços profissionais de administraçāo cartorária. Sobrevive-se no meio dos cartórios e as coisas vāo se dando por costume, por tradiçāo, porque aqui se faz assim..." ("Reformar cartórios para reformar a justiça", publicado na Folha de S. Paulo em 20 de dezembro de 2005). As exceções a esta regra são casos pontuais de autodidatismo que estão longe de serem suficientes para reduzir o problema da ineficiência gerencial. Nos últimos anos, porém, esse cenário vem mudando com velocidade crescente. Os membros do Poder Judiciário vêm percebendo que a reforma do sistema judicial tem um front silencioso, cotidiano, que independe da reforma legislativa processual: a modernizaçāo gerencial e a informatização da administração da Justiça. Diversas iniciativas inovadoras e de baixo custo, de juízes e tribunais em todo o país, começam a ser identificadas e reproduzidas, e as associaçōes de magistrados começam a investir na capacitação e formação gerencial dos magistrados que representam. Nesse sentido, cf. as práticas inovadoras de gestão no Judiciário reunidas na obra A reforma silenciosa da justiça (Org. Centro de Justiça e Sociedade da Escola de Direito do Rio de Janeiro da FGV. Rio de Janeiro: FGV, 2005).

${ }_{14}$ Cf. A. Araújo, B. Funchal. "Bankruptcy law in Latin América: past and future." Economia: Journal of Latin American and Caribbean Economic Association, p. 149-216, Fall 2005. 
ao devedor a opção pelo inadimplemento do contrato, pois torna menos ameaçadora a perspectiva de uma ação de cobrança judicial; (ii) ela reduz (em alguns casos, a zero) o valor dos bens oferecidos em garantia pelo devedor para a hipótese de inadimplência; e (iii) complementarmente a (i), ela cria incentivos para que devedores usem estrategicamente o Judiciário como um meio para postergar o pagamento das suas dívidas. ${ }^{15} \mathrm{Em}$ pesquisa realizada em 2001 por A. C. Pinheiro, verificou-se que, para $32,7 \%$ dos magistrados entrevistados, essa estratégia procrastinatória ocorreria com "muita freqüência" em ações envolvendo operações de crédito (para $27,5 \%$, ela seria "algo freqüente").

Na mesma pesquisa, constatou-se que aproximadamente $80 \%$ dos magistrados consideram que as principais causas para a morosidade do Poder Judiciário brasileiro estariam ligadas à má qualidade da legislação processual. A mesma opinião é compartilhada por empresários entrevistados em pesquisa anterior (2000) realizada por A. C. Pinheiro, ainda que, na última, a maneira pela qual a legislaçāo processual seria aplicada pelos juízes tenha sido percebida como especialmente problemática.

É difícil decodificar esse tipo de resposta para entender o que este "problema de aplicação" realmente significa, vale dizer, se ele pode ser reconduzido a um suposto viés pró-devedor no conteúdo da decisão definitiva ou a um problema de falta de punição em casos de abuso do direito de recorrer. Neste último sentido, dados recentemente divulgados revelam significativa concentração da demanda por serviços prestados pelo Judiciário do Rio de Janeiro e pelos Juizados Especiais Federais em um pequeno conjunto de empresas que figuram como rés em incontáveis açōes baseadas em idênticos fundamentos de fato e de direito - ações nas quais, em regra, são derrotadas. ${ }^{16} \mathrm{~A}$ suposição é que, por detrás deste fato, está o

15 É certo que entre esses devedores podemos incluir o próprio Poder Executivo. Sobre o tema, cf. J. Falcão, "A lentidão do executivo", publicado no jornal Correio Braziliense de 16 de fevereiro de 2006; J. Falcāo, "Reformar o poder ou reformar o sistema?", publicado no jornal Correio Braziliense de 16 de setembro de 2004.

16 Segundo o "Perfil das Maiores Demandas Judiciais no TJERJ" (2004), as açōes movidas contra instituiçōes financeiras representam $41 \%$ do total de 2 milhōes impetradas no Tribunal de Justiça do Rio de Janeiro nos dois últimos anos; em segundo lugar, ficaram as ações movidas contra concessionárias de telefonia $(14,16 \%)$ e de luz e esgoto $(7,8 \%)$. Das 714.061 novas ações distribuídas nos Juizados Especiais instalados em todo o Estado, 88\% versavam sobre a responsabilidade civil de apenas 16 empresas (sobretudo bancos, serviços públicos e administradoras de cartōes de crédito). Surpreendentemente, essas empresas foram condenadas em $68 \%$ dos casos, gerando uma dívida total no valor de $\mathrm{R} \$ 4.956 .388 .185,55$. Partindo do princípio de que essa dívida não será paga antes do fim do processo - que, em 2004, levava 923 dias, em média, para ser concluído no TJ-RJ -, e levando em conta que $2 / 3$ dos processos tramitam gratuitamente, não é difícil perceber que o Poder Judiciário do Rio de Janeiro tem sido utilizado para financiar a moratória dos devedores. Na verdade, situações similares provavelmente serāo identificadas em outros Estados. Dada a morosidade da justiça e o [ainda] baixo risco de condenaçāo por litigância de má-fé, é mais vantajoso para as empresas aguardar a tramitaçāo dos processos até a condenaçāo a investir na prevenção dos danos causados aos usuários. Esse mesmo cáiculo de custo/benefício também parece estar sendo praticado pelo Poder Executivo. Quando o "Perfil das Maiores Demandas..." foi divulgado, a AJUFE - Associação dos Juízes Federais encaminhou oficio ao Presidente do STF Nelson Jobim lembrando que, se na Justiça Estadual algumas poucas empresas contribuem decisivamente para a indesejada morosidade, na Justiça Federal é a pró- 
cálculo racional de agentes que apostam em estratégias procrastinatórias ao constatar que os custos esperados impostos pelo sistema jurídico são inferiores a seus benefícios esperados, viabilizados por um problema de lentidão da Justiça que as mesmas estratégias contribuem para acentuar.

Estudos hoje disponíveis revelam a identidade dos principais responsáveis pelo número excessivo de processos judiciais, causando o que o Ministro Nelson Jobim denominou de "congestionamento da Justiça". ${ }^{17}$ Por um lado, o Poder Público contribui decisivamente para a sobrecarga de trabalho dos juízes, sobretudo com questóes fiscais e previdenciárias, como demonstram o estudo da Universidade de Brasília sobre o Supremo Tribunal Federal e as estatísticas judiciais referentes aos Juizados Especiais Federais. ${ }^{18}$ Por outro, as grandes empresas de serviço de telefonia e energia, de cartões de crédito e bancos também são co-autoras da lentidão da Justiça. Há aqui um mecanismo perverso de retroalimentação, em que a morosidade cria incentivos para a adoção de comportamentos que agravam ainda mais a morosidade.

O rompimento desse círculo vicioso requer pelo menos duas mudanças. Em primeiro lugar, uma reforma do Código de Processo Civil, já que a legislação processual em vigor, com a profusão de recursos que ela prevê, não dá ao juiz os instrumentos suficientes de regulação do processo no sentido de desestimular a adoçāo das referidas estratégias. Se isso é verdade, então nāo é apropriado considerar esse fator predominante de morosidade do Judiciário como o resultado

pria União que precisa assumir sua responsabilidade, em especial entidades como a Caixa Econômica Federal e o INSS. Segundo o Ofício, "o Poder Público é o maior cliente do Judiciário hoje, responsável por mais de $70 \%$ do volume de processos, nos quais figura tanto como réu quanto como autor. [...] [S]omente nos Juizados Especiais Federais, criados há pouco mais de dois anos, tramitam mais de 1 milhão de açōes envolvendo o INSS e em pelo menos dois terços delas o posicionamento jurídico das teses já foi definido pelas instâncias superiores em milhares de outros processos" (Ofício AJUFE $n^{2}$ 166, de 4 de agosto de 2005; disponível no site <www.ajufe.org.br >).

17 Para o comentário de Jobim, cf. a reportagem "Justiça de R $\$ 19$ bilhôes tem nota 4,2, diz Jobim", publicada na Folha de S. Paulo em 07/05/2005. A "taxa de congestionamento" foi um dos indicadores elaborados no âmbito dos estudos estatísticos sobre o Judiciário brasileiro feitos pelo Supremo Tribunal Federal e apresentados no seminário "A Justiça em Números", realizado em maio de 2005. A taxa de congestionamento é construída a partir de uma relaçāo entre o número de decisōes que pōem fim ao processo (oferta de sentenças), de um lado, e a soma do número de novos processos com o número de processos já existentes em um determinado ano. Em 2004, na $\mathrm{I}^{\mathrm{a}}$ instância da Justiça Estadual, ficou em $80 \%$; na Justiça Federal, $84,36 \%$. Uma hipótese levantada é a de que o volume de trabalho da Justiça Federal vem caindo e tende nos próximos anos a cair na medida em que, com a estabilidade econômica, diminuiu o número de açōes envolvendo conseqüências jurídicas de planos econômicos de governo. Nesse sentido, cf. a reportagem "Sem planos econômicos, justiça tem menos açōes" (Valor Econômico, 24 de fevereiro de 2006), citando dados e conclusōes do Conselho Nacional de Justiça.

18 Segundo os professores Henrique Carlos de Oliveira de Castro, Márcio Iório e Ana Maria Nogales Vasconcelos (UnB), a Uniāo é parte em cerca de $20 \%$ dos Recursos Extraordinários que tramitam junto ao Supremo - sendo que os Recursos Extraordinários e os Agravos de Instrumento são, de longe, as açōes que mais contribuem para a carga de trabalho do STF. Os dados foram expostos no painel "Informaçōes e Estudos sobre o STF", apresentado no seminário "A Justiça em Números", realizado no Supremo Tribunal Federal em maio de 2005. Cf. a reportagem "Consultores da UNB expōem pesquisa sobre o Judiciário", publicada no site do STF (<www.stf.gov.br/notícias >) em 12 de maio de 2005. 
de comportamentos atribuíveis diretamente aos juízes. Ao contrário: a recente pesquisa produzida por Maria Tereza Sadek para a Associação dos Magistrados Brasileiros (AMB) mostra que o combate à litigância abusiva é uma das principais demanda dos próprios juízes, que expressaram apoio esmagador ( $93 \%$ de concordância entre os magistrados em atividade) a propostas de redução do número de recursos para os Tribunais Superiores. ${ }^{19}$

A segunda mudança é de responsabilidade direta dos próprios magistrados. Trata-se de aplicar os dispositivos legais existentes sobre litigância de má-fé - sobretudo os artigos do Código de Processo Civil -, que já permitem ao juiz aplicar multas quando se caracterize "abuso do direito de recorrer" ou qualquer outra conduta das partes que tenha por objetivo o retardo do término do processo. Pouco a pouco, os juízes começam a tomar consciência de que sua utilização é um mecanismo de autodefesa do Judiciário. A aplicação das multas eleva o custo esperado da estratégia protelatória e reduz incentivos à adoção de condutas que a morosidade hoje propicia. ${ }^{20}$

\subsection{Incerteza "quanto ao conteúdo": a imprevisibilidade da decisão judicial}

Na literatura econômica que se ocupa de investigar as relações entre Judiciário e mercado de crédito no Brasil, parcialidade e imprevisibilidade - componentes da incerteza quanto ao conteúdo das decisōes judiciais, nos termos sugeridos na seção anterior - aparecem como dois lados de uma mesma moeda, a da "politização" das decisões judiciais. ${ }^{21}$ O termo procura captar a percepção de empresários e executivos de que a maioria dos magistrados brasileiros deixa de lado a lei para fazer justiça social via redistribuição de recursos. Essa "politização" é a forma como se expressa, por exemplo, o "viés anticredor" que, segundo a conjectura proposta por ABL, poderia ser identificado no Poder Judiciário como manifestação particular de característica aparentemente estrutural da nossa cultura. A rigor, no entanto, é importante não perder de vista que parcialidade e imprevisibilidade podem estar associadas a fatores distintos e independentes. Uma decisāo imprevisível não é necessariamente parcial, e uma decisão parcial não é necessariamente imprevisível - ao contrário, por vezes a parcialidade é o caso limite da previsibilidade. Para ilustrar e ficarmos nas açōes envolvendo questōes de crédito: as pesquisas de opiniāo mencionadas sugerem que a expectativa dos credores é que essas açōes sejam sistematicamente decididas em favor dos devedores (previsibilidade

\footnotetext{
19 "Magistratura: caracterizaçāo e opiniōes" (2005), p. 47. Disponível no site <www.amb.com.br/portal>.

20 Para uma análise dessa questão, cf. L. F. Schuartz, "Abuso do Direito de Defesa e Reforma Processual". Revista da EMERJ, v. 8, n" 29, p. 205-219, 2005; J. Falcão, "Estratégias para a Reforma do Judiciário", in P. Bottini e S. Renault (Org.), Reforma do Judiciário. São Paulo: Saraiva, 2005.

21 A. C. Pinheiro, (2001, p. 9), porém, faz a ressalva de que “a incerteza na aplicação dos contratos introduzida pela imprevisibilidade das decisōes judiciais tem outras causas além da politizaçāo".
} 
completa, devido à ausência de imparcialidade). A própria idéia de um "viés anticredor" implica algum grau de previsibilidade quanto à parcialidade da decisão, expressa na tendência - identificável previamente - de o magistrado favorecer uma das partes.

Para dar conta dessa independência entre os conceitos de decisão imprevisível e de decisāo parcial, introduziremos, no âmbito do conceito de incerteza quanto ao conteúdo, a distinção entre dois subtipos de incerteza, a saber, a incerteza normal ou estrutural, e a incerteza patológica. As decisões judiciais que não correspondem a expectativas subjetivas (sejam essas normativas ou cognitivas) juridicamente protegidas são objeto de incerteza patológica, a decisāo judicial parcial sendo um tipo particular de decisão patologicamente incerta. Havendo dúvida razoável em relação à correção jurídica da expectativa subjetiva do agente desconfirmada pela decisão judicial, estar-se-á, ao contrário, diante de incerteza normal. Essa distinção tem declarado caráter valorativo: as decisões judiciais cujo conteúdo é imprevisível por fatores juridicamente patológicos (e. g., corrupção, proximidade pessoal ou motivações "ideológicas") são obviamente indesejáveis e devem ser tentativamente reduzidas. Já as decisões judiciais cujo conteúdo é incerto por características estruturais do processo de interpretação e aplicação do direito não são criticáveis como fatores de insegurança jurídica - ainda que possam ser motivo de frustração de expectativas subjetivas. ${ }^{22}$ É apenas a insegurança jurídica gerada por incerteza patológica, não por incerteza normal, que pode e deve ser combatida por meio de políticas judiciais específicas.

A seção 3 infra explora em mais detalhe os conceitos de incerteza normal e incerteza patológica. Por ora, nos limitaremos a mencionar as implicaçōes desta distinção no que se refere ao tipo de posicionamento normativo a se adotar em relação a eventuais "responsabilidades" do Poder Judiciário pela produçāo de um ou outro gênero de incerteza. Essa menção traz à superfície as implicações propriamente políticas que acompanham, de modo mais ou menos silencioso, os papers cujo argumento central está montado de tal forma a tornar praticamente impossível a separação entre o que é hipótese descritiva ou explicativa, de um lado, e o que é proposta normativo-política, de outro lado. Por exemplo, dado que todos nós desejamos taxas de juros menores que as vigentes, se a imprevisibilidade das decisões judiciais é um fator determinante dos níveis atuais de juros, então devemos desejar também decisōes judiciais que sejam "previsíveis". Ao não fazer a distinção entre os diferentes gêneros de incerteza - qualificados pela produção ou não de insegurança jurídica passível de ser combatida -, o argumento nos coloca diante de uma opção política (a respeito da maneira como deveria ser exercida a função jurisdicional) que já vem pré-decidida em virtude do seu "enquadramento", é dizer, dos próprios termos em que foi colocada.

22 Não se afirma que a incerteza normal nunca é capaz de gerar insegurança jurídica, mas sim que a insegurança por ela produzida é trivial e não criticável por tratar-se de aspecto inerente ao funcionamento do sistema judicial de qualquer Estado de Direito. 
O caráter artificial e potencialmente problemático dessa opção se revela, contudo, quando a referida distinçāo é explicitada e nos perguntamos, separadamente, como devemos proceder ante cada gênero de incerteza. Nesse caso, não é mais de forma alguma evidente que devamos, de um ponto de vista normativo, assumir uma posição negativa perante ambos os gêneros. Com efeito, e conforme antecipado, parte do que chamamos de incerteza normal está associada a características intrínsecas à atividade jurisdicional - e é possível, inclusive, que tal incerteza seja algo a ser valorado positivamente, por estar institucionalmente ligada, enquanto condição ou conseqüência, a elementos constitutivos de um Estado Democrático de Direito.

\section{Expectativas e as incertezas da atividade jurisdicional}

\section{I Expectativas individuais, segurança jurídica e respostas juridicamente corretas}

Uma funçāo central do sistema jurídico é generalizar e estabilizar expectativas normativas. Essa função responde, em boa medida, à demanda social por mecanismos que permitam aos indivíduos lidar com o caráter radicalmente incerto do futuro. Se, por um lado, grande parte das tentativas de prever o futuro, sobretudo no campo das relaçōes sociais, contém elementos de imaginação irredutíveis a um saber teórico que seja intersubjetivamente válido, não há, por outro, como permitir que o futuro "simplesmente venha, tal como ele vem". No âmbito político, essa constatação acerca da necessidade de intervir experimentalmente sobre o futuro, inclusive sob condições de "ignorância radical", está na base de uma visão "epistemológica" da democracia segundo a qual ninguém possui conhecimento suficiente a respeito do futuro - incluindo o conhecimento sobre as futuras conseqüências de decisões políticas alternativas - para vincular os demais, sem o seu livre consentimento, em relação aos riscos que devem incorrer e os ônus que devem suportar. ${ }^{23} \mathrm{O}$ sistema jurídico, complementarmente, "absorve" a incerteza por meio de uma estratégia que consiste - para usar a expressão de Niklas Luhmann - na "vinculação do tempo futuro" (Zeitbindung) por meio da criação de normas jurídicas que assumem, inclusive diante das prescrições de objetivos, a estrutura de programas condicionais do tipo: "dada a condição $x$, deve ser a conseqüência $y$ ". Dessa forma, reduz-se o futuro àquilo que o aplicador do direito se representa, no presente, como futuro, em suma: a algo passível de controle intersubjetivo por meio da constatação, no presente, das condições especificadas juridicamente. $\mathrm{O}$ - inatingível - futuro real (vale dizer, o presente, tal como será no futuro) pode ser provisoriamente ignorado, e as incertezas quanto à realização das

23. Ver a respeito Luis Fernando Schuartz, Die Hoffnung auf radikale Demokratie: Fragen an die Theorie des kommunikativen Handelns. Bern: Peter Lang, 2002, Capítulo VI. 
expectativas dos indivíduos podem ser substituidas por uma relativa certeza quanto à legitimidade jurídica dessas expectativas. ${ }^{24}$

Isso não é o mesmo que dizer, contudo, que a função do direito - seja da legislação, seja das decisões judiciais - é moldar-se às expectativas normativas dos indivíduos. Por exemplo, se a expectativa subjetiva de um indivíduo (ou mesmo da maioria dos indivíduos) é que a decisão judicial deva ser $D$, é óbvio que essa expectativa não obriga juridicamente o juiz a tomar a decisão $D$. Na verdade, a dissonância entre expectativas normativas individuais e direito positivo vigente é algo trivial na sociedade moderna, em que o pluralismo das visões do mundo e os conflitos de interesses que o acompanham resultam em uma multiplicidade de expectativas divergentes, irredutiveis a um denominador comum garantidor de consenso. Ainda que o moderno direito positivo contenha mecanismos de adaptação a expectativas individuais (o reconhecimento jurídico dos "usos e costumes" no direito civil e comercial, por exemplo), a regra é que as normas jurídicas funcionem como fontes de novas expectativas, que se generalizam e estabilizam - muitas vezes simbolicamente - em razão da força coercitiva dessas mesmas normas.

Isto posto, os discursos por previsibilidade - no jargão weberiano, "calculabilidade" - das decisões e segurança jurídica do agente econômico privado deveriam ser temperados com uma pitada de autodesconfiança. É somente a legitimação jurídica de uma expectativa que torna a sua proteçâo e a sua realização exigiveis em nome do princípio da segurança jurídica, e é somente esta exigibilidade que faz da decisão que a frustra algo juridicamente criticável.

Nesses termos, uma decisão cujo conteúdo é patologicamente incerto é, portanto, uma função da "distância" entre o que diz a decisão, de um lado, e o que diz a lei aplicável, de outro. Quanto menor essa distância, menos legítima é a expectativa frustrada, e menos patológica é a incerteza em relação à decisão que desconfirma essa expectativa. No limite, a incerteza se normaliza, e a expectativa subjetiva frustrada deixa de contar com o amparo do direito. A diferenciação entre incerteza normal e incerteza patológica pressupõe, logo, uma "teoria do erro jurídico" relativa à decisão judicial.

Está além dos objetivos deste artigo a caracterização do conceito de decisão judicial correta por meio de uma lista de condições necessárias e suficientes. No entanto, será interessante apresentar alguns comentários acerca de um aspecto particularmente saliente desse tema, a saber, o referente à questão da unicidade da decisāo correta. Uma concepção de segurança jurídica incompativel com a presença de incerteza estrutural quanto ao conteúdo da decisão judicial possivelmente alinha-se a uma concepção dos processos de interpretação e aplicação do direito incompatível com a existência de múltiplas respostas juridicamente corretas em alguns casos.

A noção da unicidade da decisão correta em qualquer caso concreto levado à apreciação do juiz tem no silogismo judicial o seu modelo típico para a aplicação

$\overline{24}$ Ver Niklas Luhmann, Das Recht der Gesellschaft, Frankfurt: Suhrkamp, 1995, Capítulo III. 
de normas jurídicas: a decisão correta do juiz em cada caso é conclusāo que se segue da conjunção entre uma premissa maior (a norma jurídica aplicável) e uma premissa menor (os "fatos" que compōem o caso e que devem ou não ser enquadrados na norma). ${ }^{25}$ Contudo, há atualmente um consenso relativamente amplo segundo o qual o modelo silogístico é insuficiente para dar conta da complexidade do processo de aplicação de normas jurídicas gerais a casos concretos - seja como uma descrição da atividade jurisdicional, seja como um procedimento de justificação das decisōes judiciais. ${ }^{26}$

Trata-se de problemas há muito reconhecidos e enfrentados no campo da teoria do direito. A norma aplicável não preexiste de forma acabada, esperando para ser selecionada pelo juiz, mas, ao contrário, deve ser obtida em cada caso a partir dos dispositivos legais tratados como relevantes. Além disso, uma vez definida a premissa maior, é preciso determinar se os fatos do caso se enquadram ou não na hipótese de incidência da norma. Para exemplificar os problemas envolvidos nesse processo, podemos imaginar um credor em um contrato de mútuo que pede em juízo a aplicação do artigo 590 do Código Civil:

Art. 590. O mutuante pode exigir garantia da restituição, se antes do vencimento o mutuário sofrer notória mudança em sua situação econômica.

Se a "mudança na situação econômica" tiver ocorrido quando o devedor já tiver pago algumas prestações do empréstimo, mas sem poder continuar o adimplemento de suas obrigações em virtude de alguma alteração significativa na situação macroeconômica do país - decorrente de um plano econômico de governo, por exemplo -, o devedor pode pedir ao juiz que leve em conta os dispositivos dos artigos 478 a 480 do Código Civil.

Art. 478. Nos contratos de execução continuada ou diferida, se a prestação de uma das partes se tornar excessivamente onerosa, com extrema vantagem para a outra, em virtude de acontecimentos extraordinários e imprevisíveis, poderá o devedor pedir a resolução do contrato. Os efeitos da sentença que a decretar retroagirão à data da citação.

Art. 479. A resolução poderá ser evitada, oferecendo-se o réu a modificar eqüitativamente as condições do contrato.

\footnotetext{
25 O raciocínio a ser empregado nesse processo consiste no enquadramento de uma situação de fato concreta e real (em outras palavras, "o caso") na categoria (o "conjunto de casos") designada pela hipótese de incidência de uma norma jurídica; a esse procedimento convencionou-se chamar de subsunçāo (K. Engisch, Introdução ao pensamento jurídico. 7. ed. Lisboa: Calouste Gulbenkian, 1996. p. 95)

26 A literatura sobre o assunto é vastíssima. Cf, por exemplo, K. Larenz, Metodologia da ciência do direito. 3. ed. Lisboa: Calouste Gulbenkian, 1991. p. 383-387; K. Engisch, op. cit. Partindo de perspectiva distinta, mas endossando a tese do caráter limitado do modelo silogístico, cf. H. L. A. Hart, O conceito de direito. Lisboa: Calouste Gulbenkian, 1994. Vale notar que, embora insuficiente, o modelo silogístico nāo deve ser descartado, pois representa com fidelidade ao menos parte das etapas da justificaçāo da decisão judicial (N. Maccormick, Legal reasoning and legal theory. Oxford: Clarendon, 1978).
} 
Art. 480. Se no contrato as obrigações couberem a apenas uma das partes, poderá ela pleitear que a sua prestação seja reduzida, ou alterado o modo de executá-la, a fim de evitar a onerosidade excessiva.

O credor pode exigir garantia quando o devedor pede revisão dos termos do contrato em virtude de onerosidade excessiva? Qual seria a "norma aplicável" nesse caso? O modelo silogístico nos diz o que fazer com a premissa maior, mas nāo como construí-la. A premissa maior poderia ser - e geralmente é - construída recorrendo-se a fragmentos de textos normativos espalhados por dispositivos diferentes ou até mesmo em textos legais diferentes. ${ }^{27}$ Essa construção é dificultada por potenciais conflitos normativos entre algumas ou todas as normas prima facie pertinentes - inclusive entre as mesmas e a própria Constituiçāo, já que, no Brasil, todo juiz pode, diante de um caso concreto e com efeito apenas para as partes, declarar a inconstitucionalidade de uma norma infraconstitucional e negar sua aplicação. ${ }^{28}$

Paralelamente ao trabalho de definição da norma que servirá como premissa maior do silogismo judicial, o juiz precisa decidir se os fatos do caso se enquadram ou não na hipótese de incidência da norma abstratamente considerada. ${ }^{29}$ No caso do artigo 590, uma tarefa decisiva seria determinar se um evento que afete o devedor constitui uma "notória mudança em sua situação econômica". Que propriedades um evento qualquer deve possuir para se enquadrar nessa expressão? Responder a essa pergunta pode ser mais fácil em tese do que diante de um caso concreto. As regras jurídicas são compostas por termos gerais, utilizados para identificar as classes, pessoas, coisas, açōes e situaçōes que se pretende regu-

\footnotetext{
${ }_{27}$ Todos reconhecem, por exemplo, o status constitucional do imperativo da segurança jurídica. Mas nāo é possível encontrar essa expressão escrita em nenhum dispositivo da Constituição; na verdade, quando o juiz decide com base na exigência de segurança jurídica, ele está aplicando uma norma construída a partir de uma combinação de diversos dispositivos constitucionais (art. $1^{\circ}$; art. $5^{\circ}$, caput e II, entre outros) (H. Ávila. Teoria dos princípios, 2. ed., 2003).

28 Vale notar que, para serem aplicados, todos os dispositivos envolvidos precisam ser interpretados J. Wróblewski, Constitución y teoría general de la interpretación jurídica, 1985). O conteúdo possível de termos e expressões como eqüitativamente, execução continuada e diferida, extraordinários e imprevisiveis precisa ser fixado pelo intérprete da norma com vistas à sua aplicaçāo. Contudo, quando as palavras que compōem os dispositivos comportarem diversos significados plausíveis, a determinação de um dentre esses significados possíveis na aplicaçāo da norma geral a um caso concreto possui um inafastável componente volitivo. Trata-se, em alguma medida, de uma escolha, e não de um resultado necessário de um processo cognitivo racional, como já indicado por Hans Kelsen, ainda que em um sentido mais radical (H. Kelsen, Teoria pura do direito. Sāo Faulo: Martins Fontes, 2000, especialmente o capítulo VIII). Embora o trabalho de doutrinadores e comentadores do Código Civil possa auxiliar na seleção dos significados mais plausíveis, este mesmo trabalho também representa uma escolha - mais ou menos fundamentada - entre os significados possiveis das palavras que formam os dispositivos.

29 Năo há qualquer relação definitiva de prioridade de uma tarefa sobre a outra e, na prática, é certo que o raciocínio de aplicação de normas jurídicas dependerá de idas e vindas entre a definição da premissa maior e a construçāo da premissa menor. Assim, o sentido em que se fala aqui de "etapas" do raciocínio jurídico é eminentemente didático, com o intuito de esclarecer e detalhar processos que, na prática, não podem ser separados e se influenciam mutuamente.
} 
lar. ${ }^{30}$ Ainda que possamos concordar sobre o conteúdo semântico da expressão "notória mudança", no momento de elaboração desse dispositivo não teria sido possível estabelecer exaustiva e definitivamente todas as propriedades que uma pessoa, coisa, ação ou situação deve possuir para se enquadrar na hipótese normativa.

O simples acordo sobre as definições não resolve esse problema. Segundo o dicionário Aurélio, um significado possível para "notório" seria "conhecido de todos; público, manifesto". ${ }^{31}$ Mas quantos indivíduos são necessários para que possamos dizer que "todos" conhecem o fato? Faz diferença o nível de informaçāo que cada pessoa tem sobre o evento para definirmos se ele é ou não notório? $\mathrm{Na}$ maioria dos casos, não temos maiores dificuldades para classificar ou não um fato como notório. Contudo, existe sempre uma potencial vaguidade em casos inéditos ou casos limite, que não são facilmente classificados de acordo com nossas convenções lingüísticas e, portanto, podem tornar imprecisa até mesmo a regra mais detalhada. ${ }^{32}$

Uma solução aparente para esse tipo de problema seria alterar a redação do artigo 590 de modo a tornar sua hipótese de incidência mais detalhada - por exemplo, "O mutuante pode exigir garantia da restituição, se antes do vencimento o mutuário sofrer em sua situação econômica mudança superior a $30 \%$ do patrimônio que possuía na época da celebração do contrato." Contudo, as vantagens desse maior detalhamento seriam ilusórias em diversos aspectos. ${ }^{33} \mathrm{O}$ que fazer quando a situação econômica do devedor se altera em 29,3\%? Se levarmos em conta apenas o texto normativo, o credor não poderia exigir a aplicação do artigo 590 com a redação proposta. Mas seria esta a única resposta juridicamente viável, ou mesmo a melhor resposta jurídica para o caso? É plausível afirmar que, em um caso com essas caraterísticas, impedir o credor de exigir a garantia pode ser considerado uma solução juridicamente inadequada. Isto acontece porque o texto normativo (correspondente ao que a doutrina jurídica tradicional chama de "elemento literal de interpretação") é apenas um dos fatores relevantes para a aplicação do direito. ${ }^{34}$ No caso hipotético em questão, o juiz poderia argumentar pela existência de uma discrepância entre a formulação textual e a finalidade subjacente - a proteção do direito de crédito. ${ }^{35}$

H. L. A. Hart, 1994; N. Struchiner, Direito e linguagem, 2002, p. 116.

31 Novo Aurélio: século XXI. Rio de Janeiro: Nova Fronteira, 1999.

32 N. Struchiner, 2002, p.119.

33 F. Schauer, "The convergence of rules and standards", New Zealand Law Review, 2003.

34 Para uma análise recente dos outros elementos de interpretaçāo, enfocando os tipos de argumentos que eles podem gerar, cf. H. Ávila, "Argumentaçāo jurídica e a imunidade do livro eletrônico". Diálogo Jurídico, v. $1, \mathrm{n}^{2} 5$, ago./2001.

35 Isto ocorre porque o processo de criação de regras pode ser reconstruído como uma generalização probabilística: certas características presentes em um "caso paradigmático" da conduta a ser prevenida ou promovida são selecionadas pelo criador da regra, funcionando entāo como condiçōes necessárias e suficientes para a incidência da proibiçāo ou permissāo (F. Schauer, Playing by the rules, 1991). 
Não é incomum que a finalidade subjacente da norma seja utilizada na justificação de decisões judiciais, tanto para afastar a sua incidência em um caso que se enquadrem nas expressões lingüísticas que aparecem no texto da norma, como para aplicar a norma a um caso que não se enquadre perfeitamente na sua hipótese de incidência. ${ }^{36}$ Dada essa propriedade da decisão "baseada em regras", é geralmente reconhecida a possibilidade de os juízes aplicarem diretamente a finalidade subjacente à regra, especialmente em casos nos quais o apego puro e simples à formulação normativa - isto é, a recusa em considerar qualquer outro elemento não reconduzível ao texto - possam levar a resultados tratados como "absurdos". ${ }^{37}$

Se os pontos levantados acima estiverem corretos, então é possível afirmar que os parâmetros e limites que o próprio direito fornece à sua aplicação pelos magistrados se esgotam em algum momento, sem indicar necessariamente uma única resposta correta para muitos casos nos quais a decisão judicial é, portanto, subdetermina-

O resultado é que certos casos que deveriam estar incluídos na formulação da norma não possuirão todas as propriedades necessárias ao preenchimento de sua hipótese de incidência; por outro lado, certos casos que possuem essas propriedades não se encaixam na finalidade subjacente à regra, isto é, o processo de generalização a partir de propriedades do caso paradigmático acaba abrangendo mais casos do que o necessário para atingir a finalidade para a qual a regra foi criada. Nesse sentido, fala-se que as regras possuem um caráter sobreinclusivo e subinclusivo em relação à finalidade para a qual foram criadas (F. Schauer, 1991). No caso acima imaginado, após estudos detalhados, o legislador teria determinado que, em geral, uma reduçāo inferior a $30 \%$ do patrimônio não contribui significativamente para o seu objetivo - a proteção do direito de crédito. Assim, positiva expressamente o parâmetro de $30 \%$. Ao fazer essa generalização, o legislador deixa de fora da formulação da hipótese de incidência "notórias mudanças na situação econômica" do devedor que certamente colocariam em risco a satisfação do crédito em jogo.

36 Vale ressaltar que o recurso à finalidade da norma é em si um instrumento neutro em relaçāo às teses jurídicas que pode ser utilizado para sustentar. Não é necessariamente "pró-devedor".

3:- Recorrer à finalidade da norma em detrimento do seu sentido literal é um procedimento consolidado e utilizado nas práticas judiciais de inúmeros sistemas jurídicos. Os estudos de interpretação jurídica comparada reunidos por Robert S. Summers e Neil MacCormick em Interpreting statutes: a comparative study (1991), realizados por juristas de países como EUA, Inglaterra, Itália, Polônia, França e Alemanha, entre outros, apontam para um "núcleo duro" de argumentos jurídicos que é comum à justificaçāo de decisōes das Supremas Cortes e Tribunais Constitucionais analisados (cf. especialmente $\mathrm{o}$ artigo de R. S. Summers e M. Taruffo na obra citada - "Interpretation and comparative analysis", p. 464 e seguintes). Entre esses diferentes tipos de argumentos comuns, está justamente o recurso ao propósito ou finalidade dos dispositivos legais objetos de interpretação no caso - ainda que, como reconhecem os autores, a idéia de "finalidade" ou "propósito" seja construída de maneira significativamente diferente em cada país; nos EUA, por exemplo, os juízes têm mais liberdade para reconstruir a legislação a partir de policies que não foram expressamente articuladas pelo legislador, enquanto na França tende a haver uma preocupaçāo mais acentuada em identificar o propósito que os responsáveis pela elaboração da norma tinham em mente (op. cit, p. 469). É interessante notar que o recurso a argumentos morais, políticos e/ou econômicos sem ligação imediata com o texto ou com a finalidade de normas juridicas vigentes - o que os autores chamam de razões substanciais [substantial reasons] - também integra o núcleo comum identificado na obra, sendo encontrável em todos os conjuntos de decisōes analisados, ainda que em graus variados de frequêencia e importância (op. cit, p. 470). Nāo se pode dizer, portanto, que levar em conta o impacto econômico ou social de uma dada decisão seja um fenômeno exclusivo deste ou daquele país, ou mesmo de um conjunto específico de países com características comuns - por exemplo, "países da América do Sul". 
da pelas normas vigentes ${ }^{38}$ No exemplo hipotético do credor que exige garantia do devedor que, por sua vez, pede a revisão do contrato por onerosidade excessiva, um observador desinteressado perceberia a existência de um conjunto não unitário de possíveis interpretações dos fatos e das normas envolvidas, dentro do qual nenhuma solução poderia ser facilmente excluída como "contrária ao direito vigente". É esta situação de subdeterminação que caracteriza a incerteza normal ou estrutural.

A incompatibilidade entre o reconhecimento da subdeterminaçāo das normas jurídicas e uma concepção absoluta de segurança jurídica ou previsibilidade é evidente. Para ilustrar o ponto, podemos reconstruir da seguinte forma o raciocínio de aplicação de normas jurídicas normalmente assumido como válido por demandas por segurança jurídica que não levam em conta a existência de incerteza estrutural:

(i) Os conjuntos são bem definidos e incontroversos; o procedimento de aplicação é transparente para qualquer observador.

(ii) "Dados os Fatos. Tem-se o Direito Aplicável"; "Dado o Direito Aplicável, Tem-se a Decisāo"

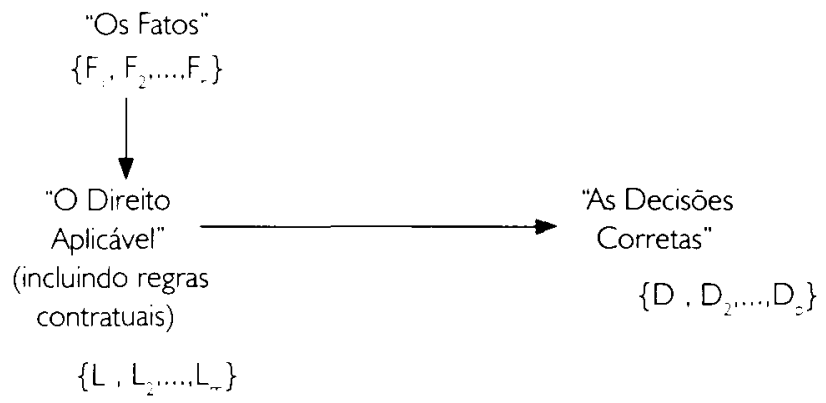

Figura 1 "Simplesmente Obedeça ao Direito": um modelo para máxima segurança jurídica.

A partir das observações desenvolvidas nas páginas anteriores, pode-se afirmar que o modelo descrito na Figura 1 não dá conta da complexidade envolvida no processo de tomada de decisão judicial. Uma reconstrução geral mais adequada dos processos de interpretação e aplicação do direito teria que reconhecer que a subdeterminação - pelos motivos já discutidos - é inevitável em algum grau. A aceitação dessa característica dos processos de aplicação do direito tem conseqüências importantes para a construção de um modelo adequado para a decisão judicial.

38 L. B. Solum, "Indeterminacy", in D. Patterson (Ed.). A companion to law and legal theory (1999), p. 490. O Direito será determinado com relação a um caso específico se e somente se o conjunto de resultados juridicamente permitidos para aquele caso possui um único elemento; por outro lado, será indeterminado com relação a um caso específico se e somente se o conjunto de resultados juridicamente permitidos é idêntico ao conjunto de resultados possíveis. 
De fato, não se trata apenas da identificação de conjuntos finitos de decisões corretas entre as quais o juiz estaria livre para escolher uma - com probabilidade desprezível de reversão ou de crítica pelos pares - enquanto solução aceitável para o caso concreto. Mais que isso, está-se diante de um processo que não segue um curso "linear" e em que cada conjunto relevante - a saber, o conjunto de fatos, o conjunto de normas aplicáveis e o conjunto de decisões corretas - não pode ser determinado de um modo univoco. Os "fatos", por exemplo, nāo são simplesmente dados ao juiz, mas sim "construídos" à luz de indícios trazidos aos autos e igualmente carentes de uma descrição que é linguisticamente mediada e, nesse sentido, inevitavelmente afetada, em parte ao menos, pela sua "visão do mundo". Além disso, como já observado, essa construção se alimenta de um movimento de "ir e vir" que vai dos "fatos" às "normas" e vice-versa. As "normas legais", por sua vez, não estão "simplesmente aí", à espera de "fatos" para posterior subsunção (como pressupõe o modelo da Figura 1), mas são - incompletamente - identificadas e têm o seu sentido concretizado juntamente com o sentido dos "fatos" em relaçāo aos quais devem ser aplicadas.

Reconstruindo o modelo da Figura 1 de forma a incorporar esses problemas, teremos:

(i) Todos os conjuntos são "fuzzy" e podem ser questionados por observadores razoáveis:

(ii) Movimento de "ida e volta" entre os conjuntos: nada é simplesmente "dado" para o aplicador

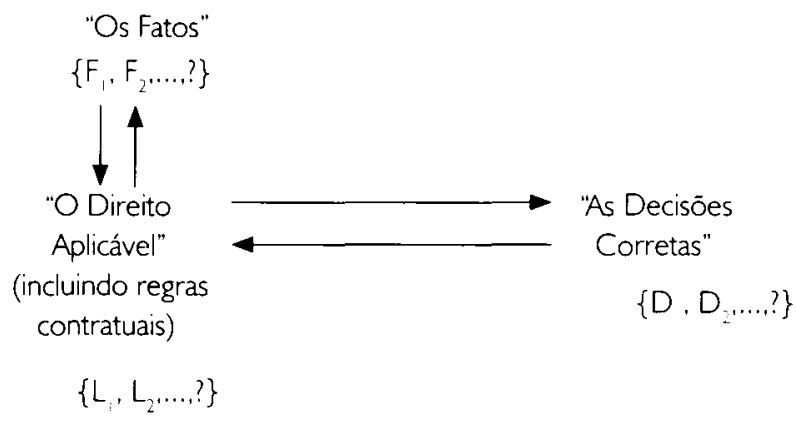

Figura 2 Um modelo alternativo de decisão judicial: introduzindo a subdeterminação.

É a existência de um conjunto difuso e nāo unitário de soluçōes juridicamente plausíveis, fruto das condições inerentes ao processo de aplicação de normas gerais a casos concretos, bem como a impossibilidade de se estipular em tese, previamente e de forma exaustiva quais decisōes integram o conjunto de decisões corretas, aquilo que justifica a distinção proposta entre incerteza normal e incerteza patológica. A segurança que o direito é capaz de fornecer é, portanto, necessariamente limitada, tendo em vista que a maioria significativa dos casos será resolvida sob condições (mais ou menos radicais) de subdeterminação jurídica; nesses casos, algum componente de incerteza é irredutível. Mas essa incerteza não é completa, 
já que o direito vigente nāo comporta toda e qualquer decisāo, por melhores que sejam os seus méritos sociais, morais ou econômicos. São as decisões judiciais que não pertencem ao conjunto de decisões juridicamente possíveis que frustram expectativas legítimas das partes, caracterizando a incerteza patológica quanto ao conteúdo, em desatenção ao princípio da segurança jurídica. Nessas condições, o máximo que se pode esperar do funcionamento de um sistema jurídico moderno bem organizado - com leis bem redigidas e instituições capazes de aplicá-las - é que ele exclua como ilegais um conjunto de alternativas decisórias que seja suficiente para permitir o planejamento dos agentes públicos e privados. Qualquer ambiçāo de certeza além desse ponto é invariavelmente ou ingênua ou ideológica.

\subsection{Conseqüencialismo vs. Automatismo Judicial?}

A compreensão das características dos processos de aplicação de normas gerais a casos concretos é decisiva para se determinar com exatidão aquilo que podemos exigir do sistema judicial. Muitas das críticas feitas à atuação do Judiciário partem da concepção de que o papel dessa instituição seria simplesmente "obedecer ao direito vigente" - o que inclui os contratos -, e não se pautar por consideraçōes "extrajurídicas", relativas, por exemplo, a preocupaçōes com redistribuição de renda. "Obedecer ao direito vigente", porém, é uma expressão que - embora não descreva de forma equivocada o papel do Judiciário - é suficientemente vaga para permitir leituras simplificadas que ignorem as peculiaridades metodológicas descritas na seção anterior.

Essa incompreensão se reflete diretamente na elaboração de pesquisas que procuram analisar o grau de obediência e da forma de obediência dos magistrados brasileiros ao "Direito" que lhes compete aplicar diante dos casos submetidos à sua apreciação. É o caso do estudo "Judiciário, reforma e economia: a visão dos magistrados", de Armando Castelar Pinheiro (2002). ${ }^{39} \mathrm{Na}$ pesquisa, uma amostra de juízes brasileiros foi colocada diante da seguinte questão: "Na aplicação da lei, existe freqüentemente uma tensão entre contratos, que precisam ser observados, e os interesses de segmentos sociais menos privilegiados, que precisam ser atendidos. Considerando o conflito que surge nesses casos entre esses dois objetivos, duas posições opostas têm sido defendidas: A. Os contratos devem ser sempre respeitados, independentemente de suas repercussões sociais; B. O juiz tem um papel social a cumprir, e a busca da justiça social justifica decisões que violem os contratos. Com qual das duas posições o(a) senhor (a) concorda mais?" Como resultado, $19,7 \%$ dos entrevistados concordaram mais com a afirmativa $\mathbf{A}$, enquanto $73,1 \%$ concordaram com a afirmativa $\mathbf{B}$ - o que, na interpretação do

\footnotetext{
39 Os estudos pioneiros no país nessa linha foram M. T. Sadek, "A crise do Judiciário vista pelos juízes: resultados da pesquisa quantitativa", in M. T. Sadek (Org.), Uma introduçāo ao estudo da justiça, Editora Sumaré, 1995; L. Werneck Vianna, M. A. R. Carvalho, M. P. C. Melo e M. B. Burgos, O perfil do magistrado brasileiro: projeto diagnóstico da justiça, AMB/IUPERJ, 1996 (posteriormente editada como - livro Corpo e alma da magistratura brasileira, Editora Revan, 1997); B. Lamounier e A. Souza, As elites brasileiras e o desenvolvimento nacional: fatores de consenso e dissenso, Idesp, 2002.
} 
autor do estudo (como de resto na interpretação de boa parte dos seus leitores), denota um "ativismo" dos juízes no sentido de favorecer os devedores e tentar transformar o momento da execução do contrato em uma oportunidade de fazer justiça distributiva.

Estes resultados são insuficientes para uma avaliação minimamente segura da parcialidade ou do respeito à lei por parte do Poder Judiciário brasileiro, especialmente quando utilizados para sustentar críticas à "politização" das decisões judiciais, as quais podem ser examinadas em dois níveis. O primeiro, e mais visível, é o nível metodológico, no qual é possível articular sérias dúvidas quanto à interpretação dos dados nos quais o argumento se baseia (respostas de magistrados a pesquisas de opinião) em termos de uma dicotomia no que se refere a possíveis "razōes de decidir", i.e.: decisão baseada no direito vigente versus decisão baseada em conseqüências sociais. ${ }^{40}$ De fato, a oposição é completamente artificial, pois o direito moderno (nāo só no Brasil!) está repleto de normas que obrigam os juízes a levarem em conta os efeitos sociais de suas decisões como uma condição de licitude. ${ }^{41}$ Mas o argumento da "politização" pode ser examinado de um ponto de vista complementar, mais rico em resultados nāo triviais.

Na sua versão típica, a crítica à decisão judicial politizada é uma crítica que está fundada em um argumento conseqüencialista: são os efeitos da decisão politizada que fazem dela algo criticável. Aparentemente, o problema da politização não estaria, assim, na estrutura conseqüencialista da inferência que suporta a decisão judicial criticada, mas na imperfeição e incompletude desta última tal como realizada pelo

\footnotetext{
40 A recente pesquisa "Magistratura: caracterização e opiniōes", de autoria de Maria Tereza Sadek, produzida e divulgada em dezembro de 2005 pela Associaçāo de Magistrados do Brasil (AMB), deu um passo importante na construção dos indicadores adequados para investigar a obediência dos juizes às normas legais vigentes. Diante da pergunta "Do seu ponto de vista, as decisōes judiciais devem orientar-se preponderantemente por parâmetros legais, atentar para suas consequiências econômicas, ter compromisso com suas conseqüências sociais?", com três respostas admissíveis (parâmetros legais, compromisso com conseqüências sociais e compromisso com conseqüèncias econômicas), os magistrados brasileiros em atividade afirmaram que os "parâmetros legais" continuam sendo um fator decisivo na tomada de decisão judicial ( $87 \%)$, seguidos de perto pelo "compromisso com as conseqüências sociais" ( $83, \%)$, ficando o "compromisso com as conseqüências econômicas" com um distante terceiro lugar $(40,5 \%)$. Como é possível que a esmagadora maioria dos juízes declare que dois fatores têm influência preponderante na formulação da decisāo? A única maneira de prover de sentido a posição dos magistrados é considerar que, na percepção deles, os dois fatores não são excludentes - ao contrário, muitas vezes o respeito aos parâmetros legais nāo apenas permite, como demanda a consideraçāo das conseqüências da decisão para sua correta aplicaçāo.
}

4i A Constituiçāo Brasileira de 1988 contém inúmeros dispositivos que poderiam ser invocados para levar o magistrado a considerar as conseqüências de cada decisāo possível antes de firmar seu entendimento sobre o caso, como, por exemplo, os artigos 225 ("Todos têm direito ao meio ambiente ecologicamente equilibrado, bem de uso comum do povo e essencial à sadia qualidade de vida, impondo-se ao Poder Público e à coletividade o dever de defendê-lo e preservá-lo para as presentes e futuras geraçōes") e 227 ("É dever da família, da sociedade e do Estado assegurar à criança e ao adolescente, com absoluta prioridade, o direito à vida, à saúde, à alimentação, à educação, ao lazer, à profissionalização, à cultura, à dignidade, ao respeito, à liberdade e à convivência familiar e comunitária, além de colocálos a salvo de toda forma de negligência, discriminaçāo, exploração, violência, crueldade e opressão"). Sobre o tema, cf. D. Werneck, Argumentaçāo conseqüencialista e Estado de direito: subsídios para uma compatibilização, trabalho apresentado no XIV Encontro Nacional do CONPEDI (Fortaleza, 5 de novembro de 2005). 
juiz. Em outras palavras, o problema não estaria no fato de o juiz orientar-se pelas conseqüências das suas decisōes no momento de tomá-las, mas, sim, no fato de ele procurar essa orientação de uma maneira inapropriada (de acordo com o crítico). No entanto, essa aparência é enganosa. O juiz ideal da crítica conseqüencialista (e usualmente econômica) da politização judicial não é o juiz que decide cada caso com vistas a maximizar, paradigmaticamente, a eficiência econômica, mas, sim, o juiz autômato, que aplica de forma quase ritualística os programas condicionais que a lei lhe oferece, com total indiferença em relação às possíveis conseqüências desse seu comportamento. A explicação para essa aparente incongruência está na suposição de que a preocupaçāo com a conseqüência já se encontra devidamente incorporada à lei, de modo que os melhores resultados sociais serão alcançados se o direito vigente for aplicado tal como existente (ou ainda, segundo visões mais sofisticadas, que o locus mais adequado, do ponto de vista institucional, para a correçāo dos efeitos, para as partes, associados a leis ineficientes, é o Poder Legislativo). O juiz deve "apenas aplicar a lei" e, assim, permitir que as conseqüências desejadas possam se tornar realidade.

Na literatura econômica, tal suposição vem normalmente expressa na fórmula simplista do "respeito aos contratos e aos direitos de propriedade". É como se o direito privado nada mais dissesse do que isso, e o resto pudesse ser reconduzido à subjetividade do juiz - à sua intenção compreensível, mas pouco esclarecida, de fazer valer contra legem a sua própria concepção acerca do que é socialmente justo em cada caso concreto. Ocorre que o direito privado - inclusive o dos países de sistemas tradicionais de common law, como os EUA e a Inglaterra - é muito mais complexo do que essa concepção pressupōe. Normas que definem (nem sempre em linguagem suficientemente precisa) hipóteses de revisão judicial de contratos e de restriçōes ao direito de propriedade são típicas e numerosas nos ordenamentos jurídicos dos países desenvolvidos..$^{42}$ Ora, como é possível conciliar a exigência do juiz autômato com um direito positivo que o obriga a fazer sob certas condições precisamente aquilo que, conforme o argumento conseqüencialista, ele não deveria fazer - i.e., modificar contratos e restringir direitos de propriedade? Uma saída possível estaria numa simples extensão da exigência formalista no que se refere aos casos de revisão contratual e restrição a direitos de propriedade: o juiz só poderá rever contratos e limitar direitos de propriedade se e quando o direito vigente o autorizar. Mas essa aparente obviedade apenas nos remete de volta aos problemas teóricos da subdeterminação da decisão e da tensão entre expectativas subjetivas e direito positivo, bem como ao problema empírico dos "reais" determinantes do comportamento do juiz. Além disso, como assegurar que esse direito privado mais complexo, que prevê vários condicionantes e limitaçōes ao direito de propriedade e ao princípio da autonomia contratual, também seria raciona-

\footnotetext{
*- Para uma visāo abrangente da produção doutrinária em diversos países sobre a cláusula da função social do contrato, por exemplo, cf. o parecer de A. J. de Azevedo, Princípios do Novo Código Civil e Desregulamentação - Direito de Exclusividade nas Relações Contratuais de Fornecimento - Função Social do Contrato e Responsabilidade Aquiliana do Terceiro que Contribui para Inadimplemento Contratual, $R T$, v. 750 , abr. 1998, p. 113-120. Agradecemos a Alessandro Octaviani pela indicaçāo bibliográfica.
} 
lizável em nome dos seus efeitos econômicos agregados? E ainda: como ficam, por exemplo, as expectativas quanto ao cumprimento dos contratos, quando estes são inevitavelmente incompletos e podem ser revistos por força de contingências imprevistas que, por definição, não foram nem explícita nem implicitamente consideradas no contrato sob forma de uma alocação de riscos e uma definição dos direitos e deveres das partes contratantes na hipótese da sua ocorrência?

Não é à toa que, na sua versão mais ortodoxa, a análise econômica do direito não prescinde de uma visão idealizada do juiz como alguém que é capaz de transitar entre os papéis do autômato que cumpre leis e contratos desenhados otimamente e o do agente ultra-racional que possui informaçōes e capacidade cognitiva suficientes para, nos casos de ambigüidade (da lei ou do contrato) e incompletude (do contrato), escolher a decisão que maximiza on the spot a diferença entre benefícios e custos esperados agregados dos indivíduos cujos interesses estão em jogo. ${ }^{43}$ Não é também à toa que a reação teórica a essa visão fantasiosa tenha assumido o formato de uma defesa qualificada do formalismo jurídico enquanto estratégia global de minimização da soma dos custos de decisão e do custo esperado de decisões equivocadas ${ }^{4+} \mathrm{e}$, no limite, da convicção de que a análise custo-benefício não logra resistir a si mesma: tendo em vista a limitada capacidade cognitiva do julgador, a incompletude das informações disponíveis no contexto do processo etc., a conclusão é que o custo esperado associado à realização de uma análise custobenefício em cada caso concreto seria maior do que o benefício esperado a ela associado. Nessas condições, o melhor a fazer é abandonar a busca da solução ótima e limitar-se à busca do "satisfatório" do ponto de vista jurídico, onde a "decisão satisfatória do ponto de vista jurídico" é a que não foi excluída do conjunto das decisões juridicamente admissíveis por ser prima facie injustificável de acordo com argumentos não conseqüencialistas - $\mathrm{e}$ isso mesmo que nem o juiz, nem tampouco o observador externo, tenham idéia precisa de aonde a decisão acabará levando.

\section{Incerteza exógena, direito positivo e Estado democrático de direito}

\section{I "Contratos Temerários"}

Ao contrário do que à primeira vista possa parecer, as causas de incerteza associada ao cumprimento de contratos no âmbito da jurisdição brasileira não se limitam aos atos do Poder Judiciário, aos atos dos juízes. Nem mesmo se limitam

43 Essa descrição da atividade judicial ideal - que consideramos pressuposta pelo estilo dominante de análise econômica do direito - guarda nítidas semelhanças com o particularismo sensível às regras analisado por Frederick Schauer (1991). Sobre o tema, cf. N. Struchiner, Para Falar de Regras. O Positivismo Conceitual como cenário para uma investigaçāo filosófica acerca dos casos dificeis no Direito. Tese de Doutorado em Filosofia, PUC-Rio, 2005.

it Cf., por exemplo, F. Schauer (1991); C. Sunstein, One Case at a Time. Judicial Minimalism in the Supreme Court (1999), bem como a discussāo realizada em C. Sunstein e A. Vermeule, "Interpretation and Institutions", Michigan Law Review, fev. 2003. 
aos atos do Príncipe em seu sentido mais amplo - atos dos Poderes Legislativo e Executivo que, ao referenciarem as decisões judiciais, acabam por interferir no cumprimento dos contratos.

Um dos problemas enfrentados em decisōes judiciais que digam respeito ao cumprimento de contratos é determinar se uma cláusula ou mesmo todo o contrato são válidos do ponto de vista jurídico. Ou seja, se a cláusula em questão é ou não merecedora de enforcement. Se, por um lado, cabe ao legislador determinar os padrōes pelos quais se determinará a legalidade, e ao juiz, interpretar esses padrōes e aplicá-los aos casos concretos, por outro, cabe às partes acionar o Judiciário e submeter à apreciação do juiz as cláusulas livremente pactuadas.

De fato, a decisão judicial não é, em regra, de iniciativa do próprio Poder Judiciário, mas, sim, das partes em conflito. A exigência de inércia na atividade jurisdicional - agir, em questōes de direito privado, apenas mediante provocação - se incorporou ao patrimônio jurídico ocidental como algo capaz de contribuir para a imparcialidade do Judiciário. ${ }^{45}$ Assim, para que se chegue à decisāo judicial em um caso envolvendo a aplicaçāo de um contrato, as partes - credor ou devedor - levam normalmente a julgamento cláusulas por elas mesmas negociadas e pactuadas. Este ato complexo - a seleção das cláusulas, a definição final de seu conteúdo e de sua redação e, sobretudo, a demanda pela apreciação de sua legalidade - interfere decisivamente no resultado da decisão judicial. No entanto, nenhuma das diferentes ações acima descritas cabe ao Estado. Ao contrário: cabem ao credor e ao devedor, ao autor e ao réu, aos agentes econômicos responsáveis pela negociação e redação do contrato.

A análise de uma decisão judicial relativa à aplicação de contratos que procure dar conta dessa complexidade precisa perceber essa decisão como o resultado da interação entre atos do Poder Público (em suas múltiplas dimensões) e atos dos contratantes. Atos, pois, tanto do Estado, quanto dos agentes econômicos em sentido estrito. Uma visão mais completa da incerteza associada ao cumprimento dos contratos que enfoque primariamente a decisão judicial não pode, portanto, deixar de considerar os atos das partes contratantes - a elaboração do contrato e a demanda pela apreciação da legalidade das cláusulas contratuais - como fatores que influenciam de forma não trivial o resultado daquela decisão e que, nessa qualidade, precisam ser considerados em qualquer análise que vise a explicar a ocorrência de decisões judiciais sistematicamente desfavoráveis ao credor. Determinar quais destes múltiplos atos - do Poder Público ou dos agentes econômicos - têm peso decisivo é matéria de constatação empírica, difícil de comprovar diante da insuficiência de

45 Como observa M. Cappelletti em sua obra Juízes Legisladores? (1993, p. 74 e ss.), a vedação de atuaçāo ex officio também tem sido levantada em análises de direito comparado como uma exigência procedimental que, em diversos sistemas jurídicos, contribui para diferenciar a atividade jurisdicional da atividade legislativa ou executiva, mesmo quando o conteúdo em si dessas atividades nāo for diferente em cada caso. 
dados e pesquisas do gênero no Brasil. ${ }^{46}$ Independentemente desta comprovação, podemos, pelo menos em tese, considerar como fatores co-determinantes de resultados interpretados como manifestaçōes de um suposto viés anticredor da decisão judicial a seleção, definição de conteúdo e redação das cláusulas contratuais trazidas pelo credor à apreciação do juiz. A não ser que se parta do princípio de que o tal viés se expressa necessariamente em uma decisão contra legem - caso em que seria fator de incerteza patológica, tal como descrita na seção anterior -, trata-se de fatores que certamente contribuem para moldar o conteúdo das decisões judiciais.

Em outras palavras, e complementando o argumento desenvolvido na primeira seção, o fato de o juiz tomar uma decisão contrária ao credor não significa evidentemente que a sua decisão reflita um viés anticredor cuja origem possa ser identificada na "vontade livre" do juiz. A fonte primária desse viés pode estar tanto nos atos do Poder Legislativo e do Poder Executivo, enquanto responsáveis pela elaboração das normas que o juiz precisa aplicar, quanto nos atos dos agentes econômicos privados - especificamente, do conjunto de credores e devedores diretamente responsáveis pelo conteúdo das cláusulas contratuais submetidas à apreciação judicial.

Há pouco propusemos uma distinção entre incerteza patológica e incerteza normal associadas à prestação da função jurisdicional sob condiçōes modernas. Agora, propomos distinguir o risco normal dos contratos, correspondente à tentativa das partes de regular a futura incerteza econômica a partir dos parâmetros legais do presente, do risco excessivo, que representa uma sobrecarrega da liberdade de contratação, caracterizando um conteúdo contratual com elevada probabilidade de ser considerado incompativel com o direito vigente. Nesses casos, dado o "potencial de ilegalidade" do contrato, não se pode assumir respaldo jurídico para as expectativas subjetivas dos agentes envolvidos, cuja satisfaçāo futura dependerá então de uma decisāo judicial possivelmente equivocada.

Evidentemente, esse raciocínio não ignora as considerações feitas em seção anterior sobre a multiplicidade de respostas juridicamente plausiveis a demandas judiciais, a qual gera uma zona de imprevisibilidade que é característica estrutural do processo de aplicação de normas jurídicas a casos concretos. É claro que as partes contratantes também farão as suas próprias interpretações do direito vigente, com vistas a determinar o risco de uma potencial ilegalidade ser eventualmente declarada em decisão futura. Mas o fato de ser difícil determinar os limites que separam as expectativas legítimas de legalidade por parte do credor das suas expectativas "excessivamente otimistas" e possivelmente ilegítimas não nos impede de constatar que o respeito a estes limites é justamente aquilo que define a responsabilidade do credor pela "oferta judicial" de decisões que lhe são contrárias e

\footnotetext{
46 Recentemente, algumas tentativas de verificação empírica da existência de algum tipo de viés na decisão judicial começaram a ser feitas no país. Cf, por exemplo, o paper de B. Ferrão e I. Ribeiro, Os juízes brasileiros favorecem a parte mais fraca? (2006), no qual se afirma a ocorrência de viés a favor da parte mais forte na relação jurídica.
} 
que formam ao menos parte do material a que comumente se aponta quando se fala de um viés anticredor.

Esse cálculo possivelmente contra legem das partes contratantes nasce no momento de celebração do contrato, mas só se revela durante a sua execução. $O$ otimismo excessivo da expectativa de legalidade quanto ao contrato fica oculto até o momento em que, provocado pelas partes, o Judiciário proclama a ilegalidade das cláusulas ou de todo o contrato. Se as partes têm liberdade de contratação apenas nos limites do direito vigente, e se, na maioria dos casos, um uso dessa liberdade que ultrapasse esses limites somente será juridicamente constatado quando o contrato for analisado pela autoridade competente (o juiz de direito), então não se pode afirmar que a decisão judicial que aplique o direito vigente e exclua a aplicação do contrato ilegal expressa algum tipo de viés judicial. Mesmo que se considere, como já discutido, que a legislação vigente expressa um viés anticredor ao tornar ilegais certas condutas que deveriam constar do repertório de ações lícitas do credor no momento da elaboração do contrato, o conteúdo da decisão já estava determinado em aspectos relevantes pela norma que preexistia ao conflito - e da qual contratantes mais esclarecidos deveriam estar cientes. Mesmo na hipótese de viés legislativo, portanto, a responsabilidade pela frustraçāo das expectativas [ilegais] das partes não pode ser atribuída ao juiz.

Alguns exemplos de contratos que expressam "otimismo excessivo" ou "expectativa temerária" quanto à sua legalidade são os seguintes:

(a) Contratos com cláusulas potencialmente conflitantes. É muito comum no momento da negociação a parte ceder na cláusula A para garantir a cláusula B. Esta estratégia pode produzir o consenso necessário à celebraçāo do negócio, mas possivelmente o juiz precisará avaliar individualmente cada cláusula para saber como deve decidir. Um exemplo pode ser encontrado nos contratos de privatização de telefonia, nos quais cláusulas proibindo a percepção de "vantagens indevidas" conviviam com cláusulas determinando o reajuste das tarifas a partir de determinados índices que, no correr da execução do contrato, mostraram-se desproporcionalmente benéficos às empresas de telefonia. Entre as duas cláusulas, o Judiciário optou pela do fair deal. O fundamento da decisão desfavorável ao credor foi encontrado dentro do próprio contrato.

(b) Cláusulas que confrontem os princípios constitucionais e a jurisprudência estabelecida. Na Inglaterra, por exemplo, um juiz julgou inválido um contrato de empréstimo, celebrado por um casal de ingleses, que estabelecia uma taxa de juros considerada incompatível com os princípios contratuais sedimentados no common law britânico. ${ }^{47}$

47 Para mais detalhes sobre o caso, cf. J. Falcão, "Lá e Cá", publicado na Folha de S. Paulo em 3 de dezembro de 2004. 
(c) Cláusulas que pretendam reduzir a interferência do Estado no exercício de seu poder de polícia com relação a fatores determinantes para a execução dos contratos. ${ }^{48}$

Denominamos de contratos temerários os que apresentam cláusulas com as características acima. São contratos que pretendem transferir para a decisão judicial a responsabilidade, seja de violar o direito vigente - no caso de uma decisão juridicamente equivocada que não afaste a aplicação das cláusulas ilegais -, seja de proclamar a ilegalidade das cláusulas aceitas pelas partes. Se o fundamento jurídico para a invalidade de contratos temerários reside na legislação vigente, na Constituição ou em cláusulas do próprio contrato, o fato de a decisāo ser desfavorável ao credor não pode ser tido como um "viés". Nesses casos, o Judiciário apenas cumpre o seu papel constitucional.

\subsection{Incerteza econômica, jurisdição e procedimento judicial}

Contratos temerários são uma manifestação particularmente importante de um fenômeno mais geral, a saber, a instabilidade do direito positivo enquanto conseqüência das incertezas geradas no ambiente do sistema jurídico. No sistema econômico, tais incertezas decorrem, em grande medida, do dinamismo próprio a uma moderna economia de mercado, na qual estruturas produtivas se encontram em um permanente processo de revolução acionado endogenamente. De fato, é a própria necessidade objetiva, imposta pela concorrência, de apropriação privada de oportunidades de ganho, que faz surgir os novos produtos, os novos processos de produção, as novas formas de organização empresarial, os novos mecanismos contratuais, em suma: as inovaçōes que afetam, de uma forma mais ou menos radical, as estruturas econômicas. Essa instabilidade estrutural é, ao mesmo tempo, um dos principais fatores responsáveis pelo progresso técnico-material das scciedades modernas e também - aqui aliada às instabilidades econômicas conjunturais, especialmente nas economias menos desenvolvidas - pelas crises que afetam os seus membros, por vezes com efeitos devastadores em termos sociais e psicológicos.

\footnotetext{
48 Um bom exemplo pode ser encontrado na cláusula 3.02, itens (a) e (b) do contrato celebrado entre o Citibank e Fundos de Pensāo brasileiros, que determinam, respectivamente: A) "O cumprimento das obrigaçōes dos Fundos de Pensāo sob este Contrato poderá ser exigido independentemente de qualquer regulamentação ou legislação que estabeleça limites, condiçōes ou restriçōes às participações acionárias e a negociaçōes de ações pelos Fundos de Pensão, incluindo quaisquer regulamentos editados pela Secretaria de Previdência Complementar ou qualquer órgāo sucessor (a 'SPC'), a Agência Nacional de Telecomunicaçōes (a 'ANATEL'), a Comissāo de Valores Mobiliários ou o Banco Central do Brasil (a 'Regulamentação Aplicável')"; B) "Os Fundos de Pensāo realizarão, nos termos deste Contrato, as aquisiçōes das Ações Objeto do Exercício da Opção de Venda nāo obstante tal aquisiçāo possa importar em desenquadramento ou qualquer outra irregularidade ou violaçāo da Regulamentaçāo Aplicável, ficando a cargo de cada Fundo de Pensão e sob sua exclusiva responsabilidade, tomar quaisquer medidas necessárias para permitir o tempestivo cumprimento de suas obrigaçōes sob as Opçōes de vendas [...]." Sobre a polêmica causada por este contrato, cf. a reportagem "Fundos admitem risco no acordo com Citi", publicada no Estado de S. Paulo em I de setembro de 2005.
} 
Essa incerteza econômica e seus subprodutos são fontes permanentes de "pressão" sobre o sistema político - sob a forma de mudanças legislativas - e sobre o sistema jurídico - sob a forma de inovaçōes contratuais (e. g., novos instrumentos de proteção contra e alocação de riscos) e demandas judiciais. Isso se observa com muita nitidez nos momentos de crise econômica, em que medidas emergenciais são adotadas provocando cascatas de novas normas jurídicas que abalam situações jurídicas preexistentes e confrontam os juízes com demandas por novas interpretações do direito vigente e alterações jurisprudenciais. ${ }^{49}$ Mas isso também pode ser observado, continuamente, em ocasiōes muito mais prosaicas - ilustrativamente, em que um par de agentes, conscientes da novidade e particularidade da relação social que mantêm um com o outro, optam pela elaboração de um contrato atípico e confiam na capacidade de adaptação (isto é, de alteração) do entendimento dos tribunais quanto à sua licitude.

Nessas hipóteses, o ponto a ressaltar é que o direito reage seletivamente às incertezas da economia por meio de adaptaçōes e transformações internas mais ou menos profundas, as quais, por sua vez, poderão desestabilizar antigas expectativas e funcionar como fontes regeneradoras de incerteza. A mutabilidade do direito moderno é, em boa medida, resultado das demandas de um ambiente (não só econômico!) que está em constante movimento. É, portanto, um erro supor que o sistema jurídico possa, por assim dizer, permanecer em um estado estacionário diante das instabilidades que caracterizam o sistema econômico, como se fosse uma espécie de reduto de estabilidade em meio ao dinamismo que afeta todas as demais esferas sociais.

A própria positividade do direito moderno, i. e., o fato de toda norma jurídica valer apenas por força e em virtude de uma decisão contingente - do legislador, do regulador, do juiz etc. -, podendo igualmente deixar de valer por força e em virtude de uma decisão da mesma natureza, pode ser vista como resposta institucional às exigências de um ambiente social que requer flexibilidade interpretativa e, em princípio, ampla possibilidade de revisão do conteúdo de qualquer norma jurídica. Isso

\footnotetext{
49 No julgamento da ADIn 493-0 (1992), que versava sobre a alteraçāo (por força da Lei $n^{2} 8.777$ de 1991) do critério de reajuste de prestaçōes nos contratos já celebrados pelo Plano de Equivalência Salarial por Categoria Profissional (PEC/CP), a Procuradoria-Geral da Fazenda Nacional defendeu a constitucionalidade da medida sustentando a tese de que a intangibilidade do direito adquirido e do ato jurídico perfeito só incide contra normas de direito privado, não contra normas de direito público. Como a lei questionada se inseria dentro do conjunto de medidas de estabilizaçāo econômica adotadas pelo Governo, possuía caráter de norma de direito público e, portanto, poderia incidir sobre os contratos ainda em execuçāo. A tese era arrojada, pois não encontrava base na jurisprudência do Supremo - que, ao contrário, indicava apenas que os efeitos de contratos em curso no dia da mudança da legislação se regulariam conforme a lei da época da constituição do contrato. Assim, é certo que a Procuradoria da Fazenda assumiu o risco de sustentar a constitucionalidade da lei com base nesse argumento. No caso, o Governo saiu perdendo. O Supremo decidiu que a distinção não era persuasiva e que o respeito ao direito adquirido e ao jurídico perfeito compreendia indistintamente as normas de direito privado e as normas de direito público, alcançando inclusive os efeitos de fatos anteriores eventualmente verificados na vigência da lei nova. Vale notar que essa única questão jurídica foi responsável por milhares de açōes levadas à apreciaçāo do Judiciário.
} 
não significa, por outro lado, que o direito perca a sua função de generalizador e estabilizador de expectativas normativas. O ponto é que, na sociedade moderna, essa função se desloca dos conteúdos das normas para os procedimentos de criação de normas: os conteúdos normativos podem variar e variam continuamente, mas isso somente deverá ocorrer tal como previsto nos correspondentes procedimentos.

Contudo, a importância da institucionalização de procedimentos no direito não se esgota aí. Diante da incerteza estrutural e subdeterminaçāo que caracterizam os processos de interpretação e aplicação de normas jurídicas, o respeito ao procedimento pode aparecer também, sob condições de estrita obediência ao princípio do contraditório, como um fator essencial para a garantia da racionalidade e legitimidade das decisões que resultam do procedimento como seus outputs. Os procedimentos judiciais poderiam funcionar como mecanismos de filtragem, servindo à separação entre argumentos consistentes e inconsistentes, e entre decisões justificáveis e injustificáveis juridicamente. Conforme antecipado, a interpretação desses procedimentos como mecanismos de generalização e estabilização de expectativas subjetivas e, a partir daí, de garantes da aceitabilidade racional das decisões que resultarem dos mesmos, requer a definição e a vigência de normas processuais que permitam conceber tais procedimentos como espécies de mecanismos de separação e de filtragem de bons argumentos. Apenas sob tal condição é razoável presumir que aquelas expectativas subjetivas que resistirem ao processo de formulação de hipóteses e objeções baseadas em expectativas subjetivas contrárias merecem de fato ser generalizadas e assumir o papel de premissas racionalmente aceitáveis das decisões que serão efetivamente tomadas. Essas observaçōes devem servir de alerta no que se refere às propostas de alteração da legislação processual no sentido do aumento da celeridade dos processos. Se, por um lado e como já apontado, há um consenso de que a reforma processual é uma condiçāo necessária para o aumento da eficiência do Judiciário, não se deve deixar, de outro lado, que a obtenção de ganhos de velocidade na tramitação dos processos venha eventualmente a ser paga com a redução das garantias inerentes ao devido processo legal.

\section{Conclusão}

Recentemente, representantes da academia, do setor empresarial e dos três Poderes da República começaram a discutir de forma mais intensa e sistemática a relação entre os atos do Estado - e, mais especificamente, dos atos decisórios dos juízes brasileiros - e a performance dos mercados financeiros no Brasil. Mencionou-se até a existência de um "viés anticredor" a caracterizar as decisões judiciais do Poder Judiciário brasileiro. Neste debate, expressões de sentido contestável como "segurança jurídica" e "previsibilidade" - que integram o repertório tanto de juristas, quanto de economistas - vêm sendo utilizadas como palavras de ordem a articular um consenso em torno da idéia de que o Judiciário está decidindo de forma distinta da que deveria decidir. 
Até o momento, porém, esta discussão tem sido conduzida a partir de fundamentos conceituais insuficientemente complexos para tratar da relaçāo entre previsibilidade e funcionamento da atividade jurisdicional. Conjecturas sobre a relação entre funcionamento da atividade jurisdicional e performance econômica não podem ser postas adequadamente à prova se não incorporarem, na sua formulação, uma perspectiva interna ao sistema jurídico, bem como um maior detalhamento no que se refere à natureza das relaçōes entre o sistema jurídico e outros sistemas sociais, especialmente o político e econômico. Neste artigo, tentou-se esboçar uma extensão do terreno conceitual no interior do qual esse importante debate poderá ser conduzido de uma maneira produtiva, permitindo inclusive testes empíricos mais robustos das conjecturas e hipóteses levantadas sobre a responsabilidade específica do Judiciário.

É preciso destacar que praticamente toda decisão judicial comporta alguma margem de incerteza quanto ao seu conteúdo que não é passível de eliminação, por estar associada a propriedades estruturais do processo de aplicação de normas gerais a casos concretos. Isso não significa, no entanto, que toda incerteza no direito seja desse tipo. As expectativas dos indivíduos quanto ao conteúdo das decisões judiciais que os afetam como destinatários diretos ou indiretos podem ser afetadas negativamente por incerteza de natureza patológica. Isso se dará quando uma expectativa juridicamente fundada for frustrada por uma decisão que não pertença ao conjunto - normalmente, não unitário - das decisões juridicamente satisfatórias diante do caso concreto. Em regra, sempre haverá alternativas decisórias que, embora frustrem as expectativas das partes, podem ser reconduzidas argumentativamente ao direito vigente que cabe ao juiz aplicar. Quando isso ocorre, teremos incerteza normal, que é um dado do sistema jurídico; caso contrário, estarse-á diante de incerteza patológica, a ser combatida por reformas institucionais e culturais que, a depender da fonte, serão mais ou menos profundas.

Além disso, sempre que uma decisão judicial frustra a expectativa de uma das partes sem violar o direito - ainda no âmbito da incerteza normal, portanto -, é preciso investigar se a fonte primária deste "viés" não estaria em esferas exteriores ao sistema judicial: atos do Poder Legislativo e do Poder Executivo, enquanto responsáveis pela elaboração das normas que o juiz aplica, ou atos dos agentes econômicos privados - especificamente, do conjunto de credores e devedores diretamente responsáveis pelo conteúdo das cláusulas contratuais submetidas à apreciação judicial. Assim, não pode ser invocada como fator de insegurança a decisão judicial que interpreta de forma contrária à expectativa das partes um contrato cujo conteúdo - escolhido por essas mesmas partes - se encontra no limiar da legalidade, muitas vezes embasado em argumentos doutrinários extremamente inovadores, mas ideologicamente comprometidos e formulados ad hoc para dar conta de problemas privados específicos.

Numa sociedade pluralista como a sociedade contemporânea, o que caracteriza um regime constituído como Estado Democrático de Direito é o que 
Adam Przeworski denomina de incerteza institucionalizada. Trata-se da incapacidade de qualquer dos grupos ou classes sociais de controlar de forma permanente e sem risco o resultado dos processos políticos. ${ }^{50}$ Uma característica de um regime ditatorial que funcionasse perfeitamente seria justamente a eliminaçāo dessa imprevisibilidade: todos saberiam de antemão que o ditador sempre ganha. Em um regime democrático, por sua vez, as regras a partir das quais se produzem decisões são previsíveis, mas os conteúdos dessas decisões são incertos. Em sentido análogo, um certo grau de imprevisibilidade das decisões judiciais - de incerteza normal ou estrutural, no sentido especificado acima - é algo que acompanha as instituições jurídicas das sociedades modernas.

Embora imparcialidade e previsibilidade sejam componentes do ideal de Estado de Direito, é possível identificar uma tensão entre ambas: no limite, a parcialidade total é o melhor modo de atingir a previsibilidade total. ${ }^{51}$ Algum grau de imprevisibilidade é condição necessária para que exista imparcialidade. Por outro lado, regras jurídicas devem funcionar como mecanismos para lidar com insegurança e incerteza produzidas em outras esferas sociais, gerando zonas de incerteza normal que sejam ao menos percebidas como suficientemente "controladas" pelas técnicas comumente usadas pelos juristas.

\section{Bibliografia}

AITH, M. O impacto do Judiciário nas atividades das instituições financeiras. PINHEIRO, A. C. (Org.). O Judiciário e a economia no Brasil. São Paulo: Sumaré, 2000.

ARAÚJO, A.; FUNCHAL, B. Bankruptcy law in Latin América: past and future. Economia: Journal of Latin American and Caribbean Economic Association, p. 149-216, Fall 2005.

ARGUELHES, D. W. Argumentação conseqüencialista e estado de direito: subsídios para uma compatibilização. In: ENCONTRO NACIONAL DO CONPEDI, 14., Fortaleza, 2005. Anais... .

ARIDA, P.; BACHA, E.; LARA-RESENDE, A. Credit, interest and jurisdictional uncertainty: conjectures on the case of Brazil. GLAVAZZI; GOLDFAJN; HERRERA (Org.). Inflation targeting, debt, and the Brazilian experience: 1999 to 2003. Cambridge, MA: MIT Press, 2005.

ÁVILA, H. Teoria dos princípios. 2. ed. Rio de Janeiro: Malheiros, 2003.

Argumentação jurídica e a imunidade do livro eletrônico. Diálogo Jurídico, v. $1, \mathrm{n}^{\circ} 5$, ago. 2001 .

so A. Pzreworski, 1984.

51 Como argumenta R. Posner, Law, Pragmatism and Democracy, 2003, p. 62. 
AZEVEDO, A. J. de. Princípios do novo Código Civil e desregulamentação: direito de exclusividade nas relaçōes contratuais de fornecimento - função social do contrato e responsabilidade aquiliana do terceiro que contribui para inadimplemento contratual. $R T$, v. 750, p. 113-120, abr. 1998.

BANCO MUNDIAL. Doing business in 2004. Disponível em: <www.bancomundial.org>. BECK; LEVINE. Legal institutions and financial development. World Bank Policy Research, Working Paper 3136, 2003.

BRASIL. ASSOCIAÇÃO DOS JUÍZES FEDERAIS - AJUFE. Oficio $n^{\circ} 166$, de 4 de agosto de 2005. Disponivel em: <www.ajufe.org.br>. Acesso em: 5 jan. 2006.

BRASIL. TRIBUNAL DE JUSTIÇA DO RIO DE JANEIRO. Perfil das maiores demandas judiciais no Tribunal de Justiça do Estado do Rio de Janeiro, 2004.

CAPPELLETTI, M. Juizes legisladores? Porto Alegre: Sérgio Fabris, 1993.

ENGISCH, K. Introdução ao pensamento jurídico. 7. ed. Lisboa: Calouste Gulbenkian, 1996.

ESTADO DE S. PAULO. Fundos admitem risco no acordo com Citi, set. 2005.

FALCĀO, J. Estratégias para a reforma do Judiciário. In: BOTTINI, P.; RENAULT, S. (Org.). Reforma do judiciário. São Paulo: Saraiva, 2005.

. Lá e cá. Folha de S. Paulo, 3 dez. 2004.

. A lentidāo do executivo. Correio Braziliense, 16 fev. 2006.

. Reformar o poder ou reformar o sistema? Correio Braziliense, 16 set. 2004.

FERRĀO, B.; RIBEIRO, I. Os juízes brasileiros favorecem a parte mais fraca? In: LATIN AMERICAN AND CARIBBEAN LAW AND ECONOMICS CONFERENCE, 10., Buenos Aires, 2006. Anais...

FERREIRA, Aurélio Buarque de Holanda. Novo Aurélio: o dicionário da língua portuguesa: século XXI. Rio de Janeiro: Nova Fronteira, 1999.

FUNDAÇÃO GETULIO VARGAS. CENTRO DE JUSTIÇA E SOCIEDADE. A reforma silenciosa da justiça. Rio de Janeiro: FGV, 2005.

GONÇALVES, F.; HOLLAND, M.; SPACOV, A. Can jurisdictional uncertainty and capital controls explain the high level of real interest rates in Brazil? In: ENCONTRO NACIONAL DE ECONOMIA, 23., 2005. Anais... ANPEC, 2005.

HART, H. L. A. O conceito de direito. Lisboa: Calouste Gulbenkian, 1994.

JUSTIÇA de R $\$ 19$ bilhões tem nota 4,2, diz Jobim. Folha de S. Paulo, São Paulo, 7 maio 2005.

KELSEN, H. Teoria pura do direito. São Paulo: Martins Fontes, 2000. 
LAMOUNIER, B.; SOUZA, A. As elites brasileiras e o desenvolvimento nacional: fatores de consenso e dissenso. São Paulo: Idesp, 2002.

LA PORTA; LOPEZ-DE-SILANES; SHLEIFER; VISHNY. Law and finance. Journal of Political Economy, 106, 6, 1998.

LARENZ, K. Metodologia da ciência do direito. 3. ed. Lisboa: Calouste Gulbenkian, 1991.

LIMA LOPES, J. R. de. Reformar cartórios para reformar a justiça. Folha de S. Paulo, 20 dez. 2005.

LUHMANN, N. Das Recht der Gesellschaft. Frankfurt: Suhrkamp, 1995.

MACCORMICK, N. Legal reasoning and legal theory. Oxford: Clarendon, 1978.

PINHEIRO, A. C. O componente judicial dos spreads bancários. In: BANCO CENTRAL DO BRASIL. Economia bancária e crédito: avaliação de 4 anos do projeto juros e spread bancário. Brasília, 2003. p. 34-43. Disponível em: <http://www.bcb.gov. br/?RED-SPREAD >. Acesso em: 10 jan. 2004.

. Concorrência e spreads bancários. Valor Econômico, 25 jul. 2003.

POSNER, R. Law, pragmatism and democracy. Cambridge: Harvard University Press, 2003.

PRZEWORSKI, A. Ama a incerteza e serás democrático. Novos Estudos CEBRAP, $\mathrm{n}^{\circ} 9$, jul. 1984 .

SADEK, M. T. Magistrados: uma imagem em movimento. In: SADEK, M. T. Magistrados: uma imagem em movimento. Rio de Janeiro: FGV (no prelo).

. A crise do judiciário vista pelos juízes: resultados da pesquisa quantitativa.

In: . (Org.). Uma introdução ao estudo da justiça. São Paulo: Sumaré, 1995.

. Magistratura: caracterização e opiniōes. Associação de Magistrados do Brasil (AMB), 2005.

SCHAUER, F. The convergence of rules and standards. New Zealand Law Review, p. 303-328, 2003.

Playing by the rules: a philosophical examination of rule-based decisionmaking in law and in life. Oxford: Clarendon, 1991.

SCHUARTZ, L. F. Abuso do direito de defesa e reforma processual. In: Revista da EMERJ, v. 8, no 29, p. 205-219, 2005.

. Die Hoffnung auf radikale Demokratie: Fragen an die Theorie des kommunikativen Handelns. Bern: Peter Lang, 2002.

SOLUM, L. B. Indeterminacy. In: PATTERSON, D. (Ed.). A companion to law and legal theory. Oxford: Basil Blackwell, 1999. 
STRUCHINER, N. Direito e linguagem: uma análise da textura aberta da linguagem e sua aplicação ao direito. Rio de Janeiro: Renovar, 2002.

. Para falar de regras. O positivismo conceitual como cenário para uma investigação filosófica acerca dos casos difíceis no direito. 2005. Tese (Doutorado em Filosofia - PUC, Rio de Janeiro.

SUMMERS, R. S.; MACCORMICK, D. N. (Org.). Interpreting statutes: a comparative study. Aldershot: Dartmouth, 1991.

; TARUFFO, M. Interpretation and comparative analysis. In: SUMMERS, R. S.; MACCORMICK, D. N. (Org.). Interpreting statutes: a comparative study. Aldershot: Dartmouth, 1991.

SUNSTEIN, C. One case at a time: judicial minimalism in the Supreme Court. Cambridge: Harvard University Press, 1999.

; VERMEULE, A. Interpretation and institutions. Michigan Law Review, v. 101, nº 4, Feb. 2003.

VALOR ECONÔMICO. Alteração em código já movimenta escritórios. São Paulo, 28 dez. 2005.

. Sem planos econômicos, justiça tem menos ações. São Paulo, 24 fev. 2006.

VIANNA, L., Werneck; CARVALHO, M. A. R.; MELO, M. P. C.; BURGOS, M. B. O perfil do magistrado brasileiro: Projeto Diagnóstico da Justiça. Rio de Janeiro: AMB/IUPERJ, 1996.

WRÓBLEWSKI, J. Constitución y teoría general de la interpretación jurídica. Madri: Cuadernos Civitas, 1985. 